\title{
Catalytic Production of Renewable Hydrogen for Use in Fuel Cells: A Review Study
}

\author{
Ilenia Rossetti ${ }^{1}$ - Antonio Tripodi ${ }^{1}$
}

Accepted: 31 December 2021

(c) The Author(s) 2022

\begin{abstract}
Hydrogen production from renewable sources is gaining increasing importance for application as fuel, in particular with high efficiency and low impact devices such as fuel cells. In addition, the possibility to produce more sustainable hydrogen for industrial application is also of interest for fundamental industrial processes, such as ammonia and methanol synthesis. Catalytic processes are used in most options for the production of hydrogen from renewable sources. Catalysts are directly involved in the main transformation, as in the case of reforming and of electro-/photo-catalytic water splitting, or in the upgrade and refining of the main reaction products, as in the case of tar reforming. In every case, for the main processes that reached a sufficiently mature development stage, attempts of process design, economic and environmental impact assessment are presented, on one hand to finalise the demonstration of the technology, on the other hand to highlight the challenges and bottlenecks. Selected examples are described, highlighting whenever possible the role of catalysis and the open issues, e.g. for the $\mathrm{H}_{2}$ production from reforming, aqueous phase reforming, biomass pyrolysis and gasification, photo- and electrocatalytic processes, enzymatic catalysis. The case history of hydrogen production from bioethanol for use in fuel cells is detailed from the point of view of process design and techno-economic validation. Examples of steady state or dynamic simulation of a centralised or distributed $\mathrm{H}_{2}$ production unit are presented to demonstrate the feasibility of this technology, that appears as one of the nearest to market. The economic feasibility seems demonstrated when producing hydrogen starting from diluted bioethanol.
\end{abstract}

Keywords Hydrogen production $\cdot$ Renewable sources $\cdot$ Fuel cells $\cdot$ Bioethanol $\cdot$ Reforming $\cdot$ Biomass gasification $\cdot$ Biomass pyrolysis

\section{Introduction}

Hydrogen is the most abundant element in the universe and raised particular interest in recent times due to its high energy content per unit mass: its enthalpy of combustion is $-286 \mathrm{~kJ} / \mathrm{mol}$. Its direct combustion, though energy efficient, is difficult due to hard thermal management for the very high adiabatic temperature raise, which imposes the selection of appropriate materials for burners and the control of $\mathrm{NO}_{x}$ emission, when combustion is carried out with air [1]. An alternative use is as fuel for fuel cells (FCs),

Ilenia Rossetti

ilenia.rossetti@unimi.it

1 Chemical Plants and Industrial Chemistry Group, Dip. Chimica, CNR-SCITEC and INSTM Unit MilanoUniversità, Università degli Studi di Milano, via C. Golgi 19, 20133 Milan, Italy electrochemical devices that are characterised by higher efficiency than internal combustion engines [2]. Indeed, the chemical to electric energy conversion may reach $60 \%$ by itself, while increasing efficiency is achieved when recovering also heat in Combined Heat \& Power (CHP) co-generation plants [3]. These features are accompanied by the production of water as only reaction product, which adds further advantages from the sustainability point of view $[4,5]$.

In spite of this, a key point is the need to obtain molecular hydrogen by transformation of hydrogen-rich substrates available in nature. This step is not at all trivial, since it affects the economic feasibility of the process and most of all its real environmental impact. If it is true that $\mathrm{H}_{2}$ conversion into FCs delivers only water, the synthesis of hydrogen involves the use of raw materials that should be extracted and transported (e.g. natural gas), harvested and transformed (e.g. ethanol from the fermentation of biomass; biomass transportation to the point of its transformation), 
etc. Irrespectively on the fossil or renewable source selected, every step needed for $\mathrm{H}_{2}$ production, purification, storage and distribution, implies direct and indirect environmental, social and economic impacts that must be carefully assessed to select the most appropriate choices [6-8].

More in general, the production of sustainable hydrogen is considered a promising solution to reduce the $\mathrm{CO}_{2}$ emissions in the automotive and industrial sectors, especially when considering efficient energy conversion systems as in the case of FCs. Furthermore, it opens new perspectives for the use of many different renewable based materials. Research is focused mainly on two fields of application: the production of hydrogen as energy vector and as chemical for industrial use. It is indeed the reactant for ammonia synthesis, a huge industrial process that uses most of the $\mathrm{H}_{2}$ produced worldwide and accounts for ca. $3 \%$ of the global energy consumption [9], stimulating the development of less impacting solutions for $\mathrm{H}_{2}$ production.

In this work we consider different options for the production of $\mathrm{H}_{2}$ from renewable sources, exemplifying some catalytic processes that are sufficiently mature and demonstrated to be proposed in the near future for exploitation. At this stage, the robust knowledge of kinetics, reaction mechanism and process design play a key role, and such topics should be early developed whenever possible to assess the real feasibility of the solution proposed.

Case histories will be also discussed of a centralised $\mathrm{H}_{2}$ production facility and of distributed CHP systems. A medium to large scale reforming plant can therefore be a solution to exploit bioethanol as a hydrogen source for centralised distribution facilities, e.g. a refuelling station. In addition, the production of electric energy via a fuel cell on board or for distributed CHP options, looks more suited to small- and micro-scale applications. In both cases the use of diluted bioethanol has been explored as a less expensive feedstock than fuel-grade ethanol. Indeed, for application in internal combustion engines ethanol must be used pure (when using dedicated fleets) or blended with gasoline (usually up to $10 \mathrm{vol} \%$ ethanol) [10]. Viceversa, in steam reforming a minimum 3:1 water:ethanol stoichiometric ratio must be used. In this view, the dehydration of ethanol from the fermentation broth can be less intensive, with considerable energy and cost savings and improvement of the environmental and economic sustainability of its use.

Moving a step further on this route, it is observed that the water condensation (to purify the reformate) and the hydrogen reaction with air (in the fuel cell) release heat at temperatures below the foreseen pinch-points of the reforming process: one approximately at the boiling point of the hydroalcoholic feed (cold feed-hot products exchange), and the other at the catalyst activation temperature (reacting mixture-combustion gases exchange). Yet these subpinch heat loads are aligned with the typical sanitary water temperatures in civilian buildings, allowing to design a CHP system suited for micro-scale distributed use.

\section{Catalytic Hydrogen Production from Renewable Raw Materials}

\subsection{Current Processes for $\mathrm{H}_{2}$ Production and Purification Suitable for Use in FCs}

Currently, ca. $95 \%$ of the $\mathrm{H}_{2}$ produced is based on fossil sources, accounting for ca. 55 million tons per year, increasing by ca. $6 \%$ annually $[11,12]$. The steam reforming of natural gas accounts for ca. $50 \%$ of $\mathrm{H}_{2}$ production, reforming of oil and naptha for ca. 30\%, 18\% is based on coal gasification and ca. $4 \%$ on electrolysis of water [12].

Steam reforming (SR) occurs through the following general reactions (R1) and (R2), exemplified for a general hydrocarbon [13]:

$\mathrm{C}_{\mathrm{m}} \mathrm{H}_{\mathrm{n}}+\mathrm{mH}_{2} \mathrm{O}(\mathrm{g}) \rightarrow \mathrm{mCO}+(\mathrm{m}+0.5 \mathrm{n}) \mathrm{H}_{2}$

$\mathrm{C}_{\mathrm{m}} \mathrm{H}_{\mathrm{n}}+2 \mathrm{mH}_{2} \mathrm{O}(\mathrm{g}) \rightarrow \mathrm{mCO}_{2}+(2 \mathrm{~m}+0.5 \mathrm{n}) \mathrm{H}_{2}$

$\mathrm{CO}+\mathrm{H}_{2} \mathrm{O} \rightleftarrows \mathrm{CO}_{2}+\mathrm{H}_{2}$

which are connected through the water gas shift (WGS) reaction (R3) [14].

Depending on the substrate, the reaction temperature is widely different, e.g. $180{ }^{\circ} \mathrm{C}$ for methanol, $400-600{ }^{\circ} \mathrm{C}$ for different alcohols or oxygenate substrates, $700-900{ }^{\circ} \mathrm{C}$ for hydrocarbons such as methane [15-17]. The catalysts are either based on noble metals (e.g. Pt or Rh) or on transition non-noble metals, the most studied being $\mathrm{Ni}$. The latter is particularly successful since at very high temperature kinetics is not the limiting factor, especially when the effectiveness factor of pellettised catalysts is as low as 5\% [18].

The process is sufficiently energy efficient from methane (70-85\%) and offers the highest $\mathrm{H}_{2} / \mathrm{CO}_{2}$ ratio. The interest is now turning towards more complex, and at the same time more sustainable substrates, but the limiting factor is a higher $\mathrm{CO}_{2}$ emission rate (up to $7-15 \mathrm{~kg} \mathrm{CO}_{2} / \mathrm{kg} \mathrm{H}_{2}$ ), that should be compensated in some way to become $\mathrm{CO}_{2}$ neutral [19].

In order to limit the energy input to this endothermal reaction, a variant is the autothermal reforming (ATR), which includes some feed of oxygen to partially oxidise the substrate, supplying the heat needed. More compact ATR reactors can be designed than for SR, though the gas purity and $\mathrm{H}_{2} / \mathrm{CO}_{2}$ ratio are more favourable for SR [20].

All these processes lead to a considerable amount of $\mathrm{CO}$ and $\mathrm{CO}_{2}$, that should be possibly removed before feeding a FC. If a Polymer Electrolyte Membrane FC is used, the 
Pt-based electrodes impose very careful removal of CO, down to few ppm. By contrast a Solid Oxide FC can be tolerant to high $\mathrm{CO}$ levels. $\mathrm{CO}_{2}$ is inert to $\mathrm{FCs}$, but it dilutes the reformate (ca. 20-25 vol\%) and can induce challenges for hydraulics in the design and rating of the cell. Very limited demonstration data are available for FCs operating with reformate than with pure $\mathrm{H}_{2}$ [21].

Very well assessed processes exist for $\mathrm{CO}$ conversion and $\mathrm{CO}_{2}$ separation [14, 22]. The WGS reaction ( $\mathrm{R} 3$ ) is conventionally operated in two stages, the former at high temperature (HT, i.e. $350-450{ }^{\circ} \mathrm{C}$ ) over $\mathrm{Fe}-\mathrm{Cr}$ catalysts to improve kinetics and convert most $\mathrm{CO}$. The second stage is carried out at lower temperature $\left(180-250{ }^{\circ} \mathrm{C}\right)$ over $\mathrm{Cu}-\mathrm{ZnO}$ catalysts, more active at lower temperature but more expensive [23]. Current trends are oriented towards a single stage of WGS at intermediate temperature, taking advantage of the development of high temperature PEM FCs that can operate at ca. $160{ }^{\circ} \mathrm{C}$ and thus can allow slightly higher $\mathrm{CO}$ content $[24,25]$.

To achieve few ppm CO concentration a further refining is needed, either through preferential oxidation or by methanation. The latter consumes some more $\mathrm{H}_{2}$, but avoids addition of air. Also in this case noble metal catalysts $(\mathrm{Pt}, \mathrm{Ru}, \mathrm{Rh}$ over alumina) or Ni-based ones are the most employed [26].

As for the $\mathrm{CO}_{2}$ removal technologies, wide experience has been derived on the post treatment of combustion flue gas and commercial technologies, fitting different flow rates and $\mathrm{CO}_{2}$ concentration, include pressure swing adsorption (PSA) or scrubbing with high-pressure or basic aqueous solutions [27].

\subsection{Emerging Processes for $\mathrm{H}_{2}$ Production from Biomass or Biomass Derived Substrates}

Alternatives are currently based on the valorisation of renewable feedstocks, but each option carries different challenges and degree of maturity. As a general classification $\mathrm{H}_{2}$ is defined as grey if derived from fossil fuels, blue if carbon capture and storage is applied, green if derived from renewables, bio if derived by bio-production [11].

One option for green $\mathrm{H}_{2}$ is biomass gasification to produce syngas and then hydrogen. Biomass is heated and loses the volatile components, leaving a $\mathrm{C}$-rich char, which is then gasified at $800-850{ }^{\circ} \mathrm{C}$. The products are $\mathrm{H}_{2}, \mathrm{CO}$ and $\mathrm{CO}_{2}$ and the latter can be further interconverted by the WGS reaction (R3). Furthermore, a set of organic molecules, condensate after the high temperature reactor zone, are collected as tar, which represents one of the main technological issues. The reaction is carried out cofeeding $\mathrm{O}_{2}$, air or steam, possibly using a catalyst in a fixed or fluidised bed reactor $[12,28]$. The thermal efficiency is not very high, 35-50\%, especially when moisture in biomass is significant. A second step with a Ni-based catalyst or with calcined dolomite can be used for gas cleaning and upgrading [29]. The economy of scale suggests very large installations, which however do not fit the supply rate of biomass in most applications. The challenge is therefore the development of small decentralised plants that are economically convenient [30]. Furthermore, the conversion of tar is a further issue, that suggests the subsequent catalytic upgrade by reforming [31-35]. Catalytic cracking of tar can be performed at temperature higher than $1000{ }^{\circ} \mathrm{C}$ and dolomite or olivine as catalyst. Tar formation can be prevented by using catalysts such as $\mathrm{Ni}, \mathrm{Pt}, \mathrm{Pd}$, $\mathrm{Rh}$ or alkaline metal oxides supported over $\mathrm{CeO}_{2} / \mathrm{SiO}_{2}$ [36]. Another strategy is to favour gasification and WGS by selective removal of $\mathrm{CO}_{2}$ by sorption with $\mathrm{Ca}(\mathrm{OH})_{2}$, obtained by high pressure hydration of $\mathrm{CaO} . \mathrm{CaCO}_{3}$ forms, which is then decomposed by calcination to accomplish $\mathrm{CO}_{2}$ recovery and regeneration of the sorbent [36].

Pyrolysis is an alternative thermochemical process for biomass conversion [37], carried out in absence of oxygen. Depending on the residence time and reaction temperature, biomass can be converted into different proportions of liquid (bio-oil), gaseous $\left(\mathrm{H}_{2}\right.$-containing) and solid products. This process can be co-adjuvated by catalysts, but the most foreseen application is the further conversion of bio-oil into $\mathrm{H}_{2}$ by steam reforming. Bio-oil is a mixture of organic components and can be easily separated into an aqueous fraction, containing water and water-soluble organics and a non water-soluble fraction. The aqueous fraction is particularly suitable for steam reforming, whereas the latter can be valorised by extraction of specialties and fine chemicals [28]. Steam reforming of the aqueous fraction of poplar-derived bio-oil led to $75 \% \mathrm{H}_{2}$ yield at $750{ }^{\circ} \mathrm{C}$, but fast deactivation of the catalyst was observed due to coking. Regeneration was accomplished by steaming at $800^{\circ} \mathrm{C}$ and high $\mathrm{H}_{2} \mathrm{O}$ /oil ratio (ca. $7 \mathrm{~mol} / \mathrm{mol} \mathrm{C}$ ), while low space velocity was suggested to prevent further deactivation [38]. Other reports indicate $\mathrm{H}_{2}$ yield between 71 and $78 \%[39,40]$ using platinum group metals supported over $\mathrm{ZrO}_{2}, \mathrm{Al}_{2} \mathrm{O}_{3}$ or $\mathrm{CeO}_{2}-\mathrm{ZrO}_{2}$.

As for gasification, also pyrolysis fits large scale production facilities and needs stronger efforts for validation, since its use is less defined in refinery and its development much more recent. In addition, the need to cope with the logistics of large scale biomass transportation is a key limit [41]. An interesting review on the opportunities of biomass pyrolysis for hydrogen production is reported in [42]. Biomass is rapidly heated without addition of oxygen and water at intermediate temperature $\left(375-525^{\circ} \mathrm{C}\right)$ forming a hydrogenrich gas and a liquid fraction, called bio-oil. The latter can be used as substrate for steam reforming, but challenges are related to the optimisation of the catalytic materials for this application, which are currently based on $\mathrm{Ni}$ as active phase. One of the major issues is the improvement of the effectiveness and attrition resistance for application in large scale 
fluidised beds. Other interesting applications are envisaged for the valorisation of the water-soluble fraction of bio-oil.

Aqueous phase reforming (APR) is a new option specifically developed for biomass valorization into $\mathrm{H}_{2}$ when aqueous solutions containing oxygenated hydrocarbons or carbohydrates are available (better if waste substrates) [43]. Low temperature is applied (up to $270{ }^{\circ} \mathrm{C}$ ) under autogenous pressure to keep a liquid phase (up to 50 bar). The low temperature limits $\mathrm{CO}$ amount in the outflowing gas and water evaporation does not occur, with considerable energy saving for the heat input to the reactor. Also in this case Ni-based or noble metal-based (mainly Pt) catalysts are used, but the productivity and selectivity are still not optimal [12]. Cleavage of $\mathrm{C}-\mathrm{C}$ bonds can occur over Pt, $\mathrm{Pd}, \mathrm{Rh}, \mathrm{Sn}, \mathrm{Ni}, \mathrm{Co}, \mathrm{Cu}$, $\mathrm{Zn}$ and various bi-metallic formulations [44], with activity in the order $\mathrm{Pt} \cong \mathrm{Ni}>\mathrm{Ru}>\mathrm{Rh} \cong \mathrm{Pd}>\mathrm{Ir}$. $\mathrm{Ni} / \mathrm{SiO}_{2}$ showed significant deactivation, while $\mathrm{Pt}$ and $\mathrm{Pd}$ based catalysts exhibit low selectivity for $\mathrm{C}-\mathrm{O}$ bond cleavage. As a compromise, Pt was the best choice, but the cost of the material makes it unsuitable for large scale applications [36].

The substrate solutions for the APR can be obtained e.g. by hydrolysis of cellulosic biomass, that can be performed under acidic conditions to produce sugars. The effectiveness is related to the $\mathrm{p} K_{\mathrm{a}}$ of the acid employed, e.g. $\mathrm{HCl}>\mathrm{H}_{2} \mathrm{SO}_{4}>\mathrm{HNO}_{3}>\mathrm{H}_{3} \mathrm{PO}_{4}$. Alternatively, alkaline conditions can be used with high reaction rate, but low sugar yield due to degradation [36].

$\mathrm{H}_{2}$ as energy vector has been also proposed as a mean to store excess electricity from renewables. For instance, wind turbine installations currently afford convenient electric energy price (0.03-0.07 \$/kWh), that suggests the opportunity to associate to wind parks electrolysers for $\mathrm{H}_{2}$ production from water. Different devices are commercially available, such as polymer electrolyte membrane electrolysers (PEM), alkaline electrolysers (AE) or solid oxide (SO) ones. Alkaline systems are available in large scale applications with relatively high efficiency (62\%) [28]. The main challenges for this application are related to the need of more active catalysts for both the hydrogen and oxygen evolution reactions (HER and OER, respectively), since large overpotentials are required in both cases due to slow kinetics [45]. Other issues are the high temperature of operation in the case of SO electrolysers and the acidic operating conditions of PEM that impose the use of noble metals as OER catalysts (mainly Ru and Ir), thus high cost. Ca. 12\% solarto-hydrogen efficiency is reported [46].

Volcano plots are usually reported, with maximum activity (exchange current density) as a function of the metalhydrogen binding energy for different noble metals. AE are preferable for large scale applications, but also in this case the highest activity is achieved with noble metal catalysts (Pt, Pd, Ru, Ir and Rh). Bi-metallic Ni-Pt formulations decorated on carbon cloths also showed very active for HER
[46]. As for non-noble metal formulations, transition metal carbides, chalcogenides or phosphides are interesting for HER, e.g. $\mathrm{Mo}_{2} \mathrm{C}$ or WC due to high electrical conductivity, $\mathrm{H}$-adsorption and d-band density state [47]. As for OER, two different mechanisms are discussed in the literature, conventional adsorbate evolution or oxygen-mediated. For the former, four concerted transfers of protons and electrons occur at the metal active site, producing an oxygen molecule either in acidic or basic conditions. The latter mechanism is instead mediated by oxygen transfer into the lattice of the catalyst. This mechanism is particularly suitable for materials rich of oxygen vacancies and with high ionic conductivity, such as $\mathrm{La}_{1-x} \mathrm{Sr}_{x} \mathrm{CoO}_{3-\delta}$ perovskites [46]. Suitable OER catalysts are $\mathrm{Ru}$ - and Ir-based oxides (also in multi-metal configuration) in acidic electrolyte or $\mathrm{Ni}-\mathrm{Fe}$ or $\mathrm{Fe}-\mathrm{Co}-\mathrm{W}$ in alkaline environment.

Solar energy can be directly stored in form of hydrogen by using semiconductors as photocatalysts. The water splitting reaction is at the basis of the process, but given the slow kinetics of oxygen oxidation, faster alternative half-reactions can be used, such as the oxidation of sacrificial agents. If waste organic molecules already present in water are used for this purpose, the process is called photoreforming and becomes particularly interesting to improve the environmental sustainability while removing a waste from water and producing an energy vector simultaneously [48-50]. The challenges in this case are mainly related to the development of the photocatalyst, that in principle should be activated by solar light, being visible-light responsive and above all sufficiently active. Very scarce productivities are reported until now with respect to rival processes that have much more demonstrated maturity and shorter time-to-market. On the other hand, the investigation of appropriate catalysts is the key issue, making the research on the catalytic material one of the most popular topics nowadays.

Bio-enzymatic catalysis is at the basis of most fermentative processes. Some of them, based on hydrogenase from anaerobic bacteria, directly aim at producing $\mathrm{H}_{2}$ starting from simple organic substrates, e.g. glucose. However, $\mathrm{H}_{2}$ yield is insufficient to justify the current costs. Alternatively, fermentation can be exploited through much more consolidated processes to produce simpler substrates from biomass. For instance, carbohydrate-containing raw materials can be fermented to obtain bioethanol in high yield, which can be further used as substrate for the production of $\mathrm{H}_{2}$ by steam reforming [51-55]. Through not yet commercialised, this is one of the most studied routes for the production of $\mathrm{H}_{2}$ from renewable substrates and the production of bioethanol from non-edible second generation biomass is even more sustainable on a long term perspective [56].

SR can be also applied to other renewable derived substrates, such as glycerol obtained as by-product of biodiesel production by transesterification of vegetable oils. For 
instance, the steam reforming of glycerol at $400{ }^{\circ} \mathrm{C}$ and 4.5 bar was performed over $\mathrm{Rh} / \mathrm{Al}_{2} \mathrm{O}_{3}$ catalyst, with maximum hydrogen yield of $2.6 \mathrm{~mol} / \mathrm{mol}$ glycerol fed [57] or over transition metal catalysts at relatively higher temperature [58-60].

Comparing the costs of the different technologies, whenever available, state-of-the-art technology offers 7 US\$/GJ for $\mathrm{H}_{2}$ produced from $\mathrm{SR}$ of natural gas or partial oxidation. If $\mathrm{CO}_{2}$ capture and storage is added, the $\mathrm{H}_{2}$ price increases by ca. $25-30 \%$. Higher price is currently estimated for biomass gasification (10-14 US\$/GJ) or pyrolysis (8.9-15.5 US\$/GJ) [12, 61].

Considering a recent economic assessment of a centralised facility for hydrogen production from steam reforming of bioethanol, competitive price was forecasted if using diluted bioethanol streams, which would avoid the energy intensive dehydration of bioethanol. The calculated minimum hydrogen selling price would be $1.91 \mathrm{USD} / \mathrm{kg}$, to be compared with a present standard value of the one obtained from methane steam reforming (1.80 USD/kg) [62]. This calculation was made for a system capable of producing 7793 ton/year of $\mathrm{H}_{2}\left(9886 \mathrm{Nm}^{3} \mathrm{~h}^{-1}\right)$ starting from 40,000 ton/year of bioethanol $[63,64]$. Due to its high technical maturity and competitive cost over rival technologies, the steam reforming of bioethanol is further deepened in the following paragraphs, deepening and newly elaborating the results from selected papers.

\section{Case History: Ethanol Steam Reforming}

\subsection{Design and Validation of Integrated Plants for Hydrogen Production by Ethanol SR}

Ethanol SR has been selected as case history to present the main steps towards process deployment. This example is indeed at a sufficiently advanced research stage to allow the presentation of demonstration projects, integrated process design and economic assessment. Furthermore, it is based on a widely exploitable liquid raw material, obtainable everywhere form different biomass, adaptable to different plant size and easy to transport [65-67]. Very recent reviews detail the production of hydrogen from bioethanol [13, 68, 69]. Examples of this application are described in the following. $\mathrm{Ni}, \mathrm{Co}$ and $\mathrm{Cu}$-based catalysts were developed for this application [70-75] and based on detailed kinetic modelling [76, 77] two different plants were simulated: (1) a small scale fuel processor coupled with a fuel cell for residential size CHP [78-83] and (2) an industrial scale plant for centralised hydrogen production, with economic assessment [63, 64]. The details for each system, the equipment sizing and models validation are reported in the cited references. In this section we newly elaborated some aspects of both plants to highlight their main features and application potential.

A $5 \mathrm{~kW}_{\text {electric }}+5 \mathrm{~kW}_{\text {thermal }}$ CHP system has been validated starting from $96 \mathrm{vol} \%$ bioethanol and using either a standard PEM FC operating at $80{ }^{\circ} \mathrm{C}$ and a high temperature PEM FC working at $160{ }^{\circ} \mathrm{C}[21,84]$. The system was based on a pre-reformer and a main reformer, high (HT-) and low (LT-)temperature WGS reactors and two methanators to achieve $<20 \mathrm{ppm}$ CO to feed the low temperature PEM FC. A modification of the layout with a PEM FC working at $160{ }^{\circ} \mathrm{C}$ allowed the removal of both the methanation reactors, but the FC operation was much less reliable.

A new hybrid turbofan with a molten carbonate fuel cell (MCFC) has been proposed, including a steam reformer, a water gas shift reactor and a catalytic burner [85]. Five feedstocks have been compared, ethanol, methane, hydrogen, dimethyl ether and methanol, including fuel blends. The results were also compared with a kerosene-based turbofan that can produce $42 \mathrm{MW}$ with $59 \%$ energetic efficiency and $71 \%$ exergetic efficiency, whereas the hybrid MCFC turbofan can produce $40 \mathrm{MW}$ by mixing all the five alternative fuels, but with higher performance of $65 \%$ and $80 \%$ energetic and exergetic efficiencies, respectively. The $\mathrm{CO}_{2}$ emissions were reduced by $75 \%$.

The steam reforming of methane presented the lowest water footprint per $\mathrm{kg}$ of $\mathrm{H}_{2}$ produced $\left(0.257 \mathrm{~m}^{3} / \mathrm{kg}_{\mathrm{H}_{2}}\right)$, followed by glycerol $\left(0.768 \mathrm{~m}^{3} / \mathrm{kg}_{\mathrm{H}_{2}}\right)$ and bioethanol reforming $\left(9.651 \mathrm{~m}^{3} / \mathrm{kg}_{\mathrm{H}_{2}}\right)$. The exergo-environmental analysis shows that the main bottlenecks identified are related to exergy destruction in the burners (52.46-57.32\%), reformers (2.48-21.72\%) and heat exchangers (19.45-32.61\%), which are all aspects to be considered during optimisation of this process [86]. Thus, preventing external water addition through the use of diluted bioethanol improves the water footprint of the process, together with the heat integration and energy efficiency of the system.

To this end, multi-scale energy integration is needed, considering the coupling of different high-and low temperature units of the plant, as exemplified in detail in paragraph 3.4 and optimising the thermal coupling at the meso-scale, e.g. between the SR reactor and the burner. For instance, the integration of ethanol steam reforming and ethanol combustion in a parallel-plates reactor (size $1 \mathrm{~kW}_{\text {thermal }}$ ) is proposed through a mathematical model of a non-adiabatic reactor and the associated heat exchangers. The influence of the insulation of the reactor and heat exchangers, the fuel concentration, fuel distribution policy to the reactor and flowrates are considered, pointing out the importance of heat losses that represent ca. $35-50 \%$ of the heat released by the combustion [87].

Originally developed kinetics was used to design an integrated process of $\mathrm{H}_{2}$ production from ethanol, which includes a parallel-plate reactor, a shell-and-tube membrane 
unit, and auxiliary units. Satisfactory thermal integration with efficiencies from 43 to $47 \%$ based on lower heating values, for a stream of the order of $10 \mathrm{~mol}_{\mathrm{H}_{2}} / \mathrm{h}$ [88].

The integration of thin Pd-based membranes for $\mathrm{H}_{2}$ separation in a fluidized bed catalytic reactor for ethanol autothermal reforming has been demonstrated for over $50 \mathrm{~h} .5$ thin Pd-based alumina-supported membranes and a $3 \mathrm{wt} \%$ $\mathrm{Pt}-10 \mathrm{wt} \% \mathrm{Ni}$ catalyst deposited on a mixed $\mathrm{CeO}_{2} / \mathrm{SiO}_{2}$ support were used, with $\mathrm{H}_{2}$ recovery factor up to 70 . The most critical part of the system was the sealing of the membranes, where most of the gas leakage was detected. A fluidized bed membrane reactor model for ethanol reforming was also validated with the experiments and used to design a small reactor unit for domestic use: $0.45 \mathrm{~m}^{2}$ membrane area was needed to feed a $5 \mathrm{~kW}_{\text {electric }}$ PEM FC [89].

A high temperature PEM FC integrated with a reformer has been studied considering the efficiency of different layouts and fuels. Ca. $60 \%$ heat is needed to preheat the reformer fuel when increasing its dilution with steam form $\mathrm{S} / \mathrm{C}=4$ to 6 . Also in this case the key to improve the efficiency of the system is the thermal integration [89].

The techno-economic analysis of an ethanol-to- $\mathrm{H}_{2}$ plant to feed on board PEM FCs has been considered using $\mathrm{Rh} /$ $\mathrm{CeSiO}_{2}$ as reforming catalyst and $\mathrm{Pt} / \mathrm{ZrO}_{2}$ for the WGS step. Monolith structured catalysts were developed, sufficiently stable towards coking [90]. As also pointed out in [63, 64], the $\mathrm{H}_{2}$ production cost was significantly OPEX sensitive and mainly affected by the ethanol price [90]. The $\mathrm{H}_{2}$ production cost obtained using Brazilian ethanol $\left(0.81 \mathrm{US} \$ / \mathrm{L}_{\text {ethanol }}\right)$ was 8.87 US\$ $/ \mathrm{kg}_{\mathrm{H}_{2}}$, lower than the current market prices (13.44 US $\$ / \mathrm{kg}_{\mathrm{H}_{2}}$ ) practiced at $\mathrm{H}_{2}$ re-fuelling stations in California [90].

Finally, examples of catalytic membrane microreactors have been recently reviewed, highlighting examples of fuel processing (e.g. reforming of alcohols) [91]. The inherent advantage of micro-reactors and membrane separation are the enhanced heat and mass transfer and better catalytic efficiency. Compact configurations are made available through lab-on-a-chip technologies, suited for portable or mobile devices.

\subsection{Mechanism, Kinetics and Thermodynamics}

Whenever a catalytic process has been demonstrated valid at lab scale, the scale up should rely on robust knowledge of kinetics and thermodynamics, at the basis of reactor and process design. Heterogeneous catalytic kinetics is for sure more complex to assess than for homogeneous reactions and implies also hypotheses on the future size and shape of the catalyst to estimate its effectiveness factor.

The mechanism of the ethanol steam reforming has been extensively studied in the past years, both theoretically [92, 93] and experimentally [70, 76, 77, 83, 93-97]. Nickel (with various promoters) has often been preferred over noble metal catalysts, because is as active but less expensive [70, 71, $74,75,95,98-106]$. Depending on the catalyst support and active material, the adsorbed ethanol can be activated by a first abstraction of the oxygen-bound hydrogen. Some ethanol can then be lost by dehydration to ethylene, while the reforming path is generally believed to involve a first oxidative dehydrogenation to acetaldehyde followed by the $\mathrm{C}-\mathrm{C}$ bond break and steam-reforming of the resulting methane [76, 107, 108]. The importance of the methane reforming reaction over the $\mathrm{CH}_{4}$ conversion to $\mathrm{CO}_{2}$ and water-gas shift equilibria depends on the peculiar catalyst properties and reaction temperature (usually in the range $400-600{ }^{\circ} \mathrm{C}$ ) $[95,109]$.

In general, the theoretical output of $6 \mathrm{~mol}$ of $\mathrm{H}_{2}$ per mole of ethanol (at the balanced ratio of $1 \mathrm{~mol}$ of ethanol and 3 of water) is not reached due a residual presence of methane [110]. Though water molecules may hamper the ethanol absorption on acidic supports (mainly alumina) [111], water/ alcohol ratios higher than $3 \mathrm{~mol} / \mathrm{mol}$ have been successfully tested [79, 97, 111], either for the fact that water undergoes a dissociative absorption turning into the active moieties $-\mathrm{OH}$ and $-\mathrm{H}$, and for its role in reforming and removing the coke formed by ethylene polymerization or by $-\mathrm{CH} \cdot$ aggregation into soot.

A reaction network compliant with the above sketched mechanism (Fig. 1) can be built to different complexity levels [76, 94, 112-117], with a heuristic or microkinetic approach

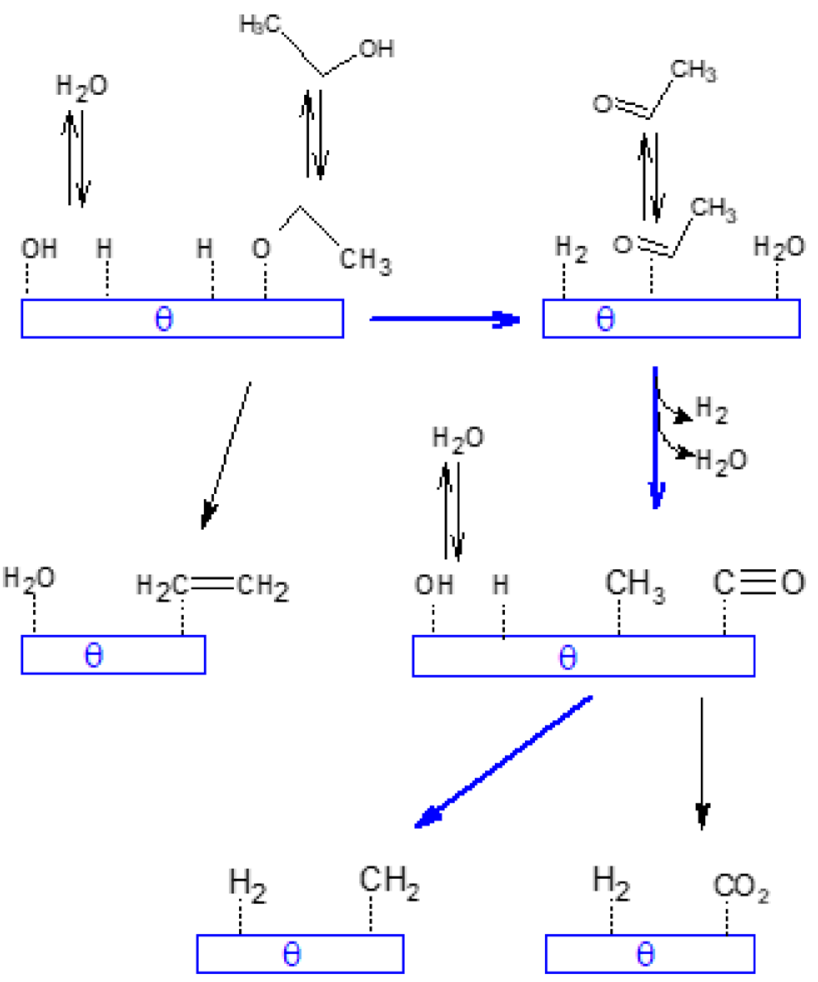

Fig. 1 Mechanism of ethanol reforming 
[118]. The latter solution has been worked out successfully and furtherly adapted to a set of proprietary data [76, 77], and can be used to calculate in detail the thermal profile and the material balances rising in a reformer:

$\mathrm{CH}_{3} \mathrm{CHO} \rightarrow \mathrm{CH}_{4}+\mathrm{CO}$

$\mathrm{CH}_{3} \mathrm{CH}_{2} \mathrm{OH}+\mathrm{H}_{2} \mathrm{O} \rightarrow \mathrm{CO}_{2}+2 \mathrm{H}_{2}+\mathrm{CH}_{4}$

$\mathrm{CH}_{4}+2 \mathrm{H}_{2} \mathrm{O} \rightleftarrows \mathrm{CO}_{2}+4 \mathrm{H}_{2}$

$\mathrm{CO}_{2}+\mathrm{H}_{2} \rightleftarrows \mathrm{CO}+\mathrm{H}_{2} \mathrm{O}$

(reverse R3)

$\mathrm{CH}_{3} \mathrm{CH}_{2} \mathrm{OH} \rightarrow \mathrm{CH}_{3} \mathrm{CHO}+\mathrm{H}_{2}$

$\mathrm{CH}_{3} \mathrm{CH}_{2} \mathrm{OH} \rightarrow \mathrm{CH}_{2} \mathrm{CH}_{2}+\mathrm{H}_{2} \mathrm{O}$

$\mathrm{CH}_{2} \mathrm{CH}_{2} \rightarrow 2 \mathrm{C}+2 \mathrm{H}_{2}$

The kinetic equations and the regressed parameters are listed in the original work [76], depending on the dataset on which the retrofit has been operated (i.e. on the catalyst type).

Nevertheless, it has to be pointed out that this set of rate equations may present some calculation drawbacks Especially due to the presence of many enthalpy-related parameters, the system is very sensitive to temperature variations. Therefore, the adoption of a simpler system of heuristic equations can be considered to achieve a preliminary model of a reformer (especially if included in a relatively complex flowsheet), after the review of available literature models [119]:

$\mathrm{CH}_{3} \mathrm{CH}_{2} \mathrm{OH} \rightleftarrows \mathrm{CH}_{3} \mathrm{CHO}+\mathrm{H}_{2}$

$r_{10}=k_{10} e^{\frac{E_{a 10}}{R T}} \frac{y_{E t O H}\left(1-e^{A+\frac{B}{T}} Q\right)}{D}$

$\mathrm{CH}_{3} \mathrm{CHO} \rightleftarrows \mathrm{CO}+\mathrm{CH}_{4}$

$r_{11}=k_{11} e^{\frac{E_{a 11}}{R T}} \frac{y_{A c H}\left(1-e^{A+\frac{B}{T}} Q\right)}{D}$

$\mathrm{CH}_{4}+\mathrm{H}_{2} \mathrm{O} \rightleftarrows \mathrm{CO}+3 \mathrm{H}_{2}$

$r_{12}=k_{12} e^{\frac{E_{a 12}}{R T}} \frac{y_{C_{4}} y_{H_{2} O}\left(1-e^{A+\frac{B}{T}} Q\right)}{D^{2}}$

$\mathrm{CO}+\mathrm{H}_{2} \mathrm{O} \rightleftarrows \mathrm{CO}_{2}+\mathrm{H}_{2}$ $r_{3}=k_{3} e^{\frac{E_{a 3}}{R T}} \frac{y_{C O} y_{H_{2} O}\left(1-e^{A+\frac{B}{T}} Q\right)}{D^{2}}$

$$
\begin{aligned}
D= & 1+K A_{2} y_{E t O H}+K A_{3} y_{H_{2} O}+K A_{4} y_{H_{2}}+K A_{5} \frac{y_{H_{2} O}}{y_{H_{2}}^{0.5}} \\
& +K A_{6} \frac{y_{C H_{4}}}{y_{H_{2}}^{0.5}}+K A_{7} y_{C O}+K A_{8} y_{H_{2}}^{0.5}
\end{aligned}
$$

where $\mathrm{Q}$ are the reaction quotients and the parameters are as reported in Table 1. $Y_{i}$ represent the molar fractions of the respective species, $r_{i}$ are the reaction rates of the specified reaction, $\mathrm{k}_{\mathrm{i}}$ the preexponential factors, $\mathrm{E}_{\mathrm{ai}}$ the activation energies and $\mathrm{KA}_{\mathrm{i}}$ are adsorption constants.

Notice that some equilibrium constants in the above equations are modified, with respect to the original values reported by the authors, to correct the fugacities at $10 \mathrm{bar}$ (i.e. the supposed pressure for the process described in the following) with respect to the atmospheric pressure of the lab tests from which they were retrieved.

The first, complete formulation is used to simulate a reformer for distributed small scale CHP, while the abridged reaction set is used for the more extended diagram of a centralised large scale $\mathrm{H}_{2}$ production. In addition, in the former case, the water-gas shift and methanation steps after the reformer are assumed in equilibrium, whereas for centralised hydrogen production, the high temperature water gas shift stage was still considered in equilibrium, while the lower temperature reactor downstream (that can actually modify the process balances) was modelled after the reviewed literature [120].

When designing a process using simulators, the appropriate thermodynamic methods must be selected in order to avoid wrong estimation of phase and chemical equilibria. Often, different sections of a complex system need definition

Table 1 The parameters $\mathrm{KA}_{2-8}$ have the same form as the reaction constants $\mathrm{k}_{1-\mathrm{n}}$

\begin{tabular}{lllll}
\hline & $\mathrm{k}_{0}(\mathrm{kmol} / \mathrm{s} \mathrm{kg})$ & $\mathrm{Ea} / \mathrm{R}(\mathrm{K})$ & $\mathrm{A}$ & $\mathrm{B}$ \\
\hline $\mathrm{r} 1$ & 11.4 & -3825 & -14.7 & 8116 \\
$\mathrm{r} 2$ & 8.42 & -2983 & -14.7 & -1609 \\
$\mathrm{r} 3$ & $9.87 \mathrm{e} 6$ & $-14,313$ & -53.0 & 26,154 \\
$\mathrm{r} 4$ & $1.06 \mathrm{e} 6$ & -7264 & -4.39 & -4657 \\
KA2 & 4.1 & 596.5 & & \\
KA3 & $5.0 \mathrm{e}-6$ & 6845 & & \\
KA4 & $7.4 \mathrm{e}-4$ & 8030 & & \\
KA5 & $1.2 \mathrm{e}-6$ & 6440 & & \\
KA6 & $6.8 \mathrm{e}-9$ & 8025 & & \\
KA7 & $5.6 \mathrm{e}-9$ & 3260 & & \\
KA8 & $1.0 \mathrm{e}-8$ & 9565 & & \\
\hline
\end{tabular}


through different models, to be validated against experimental data. According to our experience the following choices are appropriate for the different units.

Process simulation has been carried out with Aspen PLUS V8.8 or following, retrieving the thermodynamic data from the PURE32 databank. The thermodynamic model used for the description of the gas phase is the Peng-Robinson equation of state, except for several heat exchangers dealing with a substantial liquid fraction of ethanol-water mixture, which is strongly non-ideal. The latter is better described by the NRTL method, implementing the Wilson mixing rules.

The $\mathrm{CO}_{2}$ separation is achieved by coupling an absorption and a stripping column, or through an expanded pressureswing section. In the latter case, the gas phase is treated with the RKS equation, while the liquid phase with the NRTL model, whereas for absorption using an aqueous solution of amines (MDEA), the electrolytic acid-base equilibria must be computed.

Methane, hydrogen and carbon monoxide solubilities are calculated with the Henry constants. This model is useful to correlate the solubility of gases in liquids as a function of their absolute or partial pressure. The relationship between liquid phase concentration and pressure in the gas phase is usually linear for dilute systems. Calculations of phase partitions with the Aspen Plus ${ }^{\Theta}$ database to reproduce literature data [121-126] are reviewed throughout Fig. 2, which reports the mole fractions of each compound in the liquid phase as a function of temperature. The same Fig. 2 also compares the experimental data retrieved from the literature vs. the ones calculated in liquid phase through the Henry model.

Accurate predictions of solubility are available for $\mathrm{CO}_{2 \text { (liq) }}, \mathrm{H}_{2} \mathrm{O}_{\text {(vap) }}$ and $\mathrm{CH}_{4}$ partition between the liquid and the gas. The Henry constant for Hydrogen may need a revision in further developments, but in this specific case the operating conditions used to simulate the plant are in a lowtemperature region (below $50{ }^{\circ} \mathrm{C}$ ) or in a high-pressure one, where the default parameters provide a satisfactory description of hydrogen partition between the gas and liquid phases.

\subsection{Design of a Medium-Scale Centralised Hydrogen Production}

The size selected for a bioethanol to hydrogen production facility is of $4.6 \mathrm{t} / \mathrm{h}$ of ethanol diluted with $3 \mathrm{~mol}$ of water per mole of alcohol, i.e. at the stoichiometric ratio. This corresponds to the ethanol produced by a mediumsize bio-refinery [127]. Starting from an already diluted mixture, it is implicitly considered that the prior distillation up to azeotropic ethanol is not needed. The reaction pressure was set to 10 bar, values even higher than this are common in reforming plants in order to limit the piping volume, though unfavorable for thermodynamic reasons (the number of moles in the gas phase increases during the reaction). The overall layouts of methane reforming plants $[128,129]$ have been reviewed as starting points for the design of this new plant for ESR.

Figure 3 reports the layout of the reforming reaction section. The feed is pumped through a heat exchanger that recovers part of the products heat and is fed to the reforming reactor, which includes multiple catalytic beds and is thermally sustained by a burner. The latter is fed with ambient air and the purge flow from the Pressure Swing Adsorption (PSA) unit. Both the radiative direct heating power and the convective residual heat content of the burner off gases are fully exploited for heating. The products of reaction are sent to a HT-WGS reactor and then to a LT-WGS one. Various heat exchangers are shown in the flowsheet to highlight the importance of thermal recovery to improve the overall process efficiency.

The fate of the reformate may be different depending on the application. For instance, in Fig. 4 the production of pure $\mathrm{H}_{2}$ is illustrated. Separation of excess water is achieved by flash separation, while $\mathrm{CO}_{2}$ is removed by absorption with basic solutions of alcanolamines. A double column is represented in Fig. 4, the former for the absorption of $\mathrm{CO}_{2}$ and the second for amine regeneration. Final $\mathrm{H}_{2}$ purification is accomplished by PSA. The purge gas of the PSA is used as fuel for the burner of Fig. 3.

Figure 5 details the performance of the reforming reactor, describing the profile of conversion and hydrogen concentration vs. temperature along the three catalytic beds. The respective temperature profiles, divided between the zones where heating is done by irradiation or by convection, are also reported. The detail of gas composition outflowing from the different units are reported in Fig. 6. Hydrogen concentration progressively increases through the three reforming beds and thanks to the following WGS units. $\mathrm{CO}_{2}$ and the remaining impurities are fully eliminated with the two units of $\mathrm{CO}_{2}$ absorption and PSA. Possibly, a single PSA may be designed also to remove $\mathrm{CO}_{2}$, but it is a major component and this would require oversizing of this unit.

The process depicted in Figs. 3 and 4 simulates a reformer conceptually divided into a radiant and convective section via the following criteria:

- part of the heat released by the burned fuel just before the radiant section is actually used to heat the feed, so the combustion is not adiabatic and the higher temperature is fixed to $1000-1100{ }^{\circ} \mathrm{C}$ : the resulting heat surplus at the burner is used as an input to the last feed heater;

- the hot flues are split in three, to simulate a parallel cross flow between the hot gases and the process stream in the radiant section: the first part heats up the ethanol before 

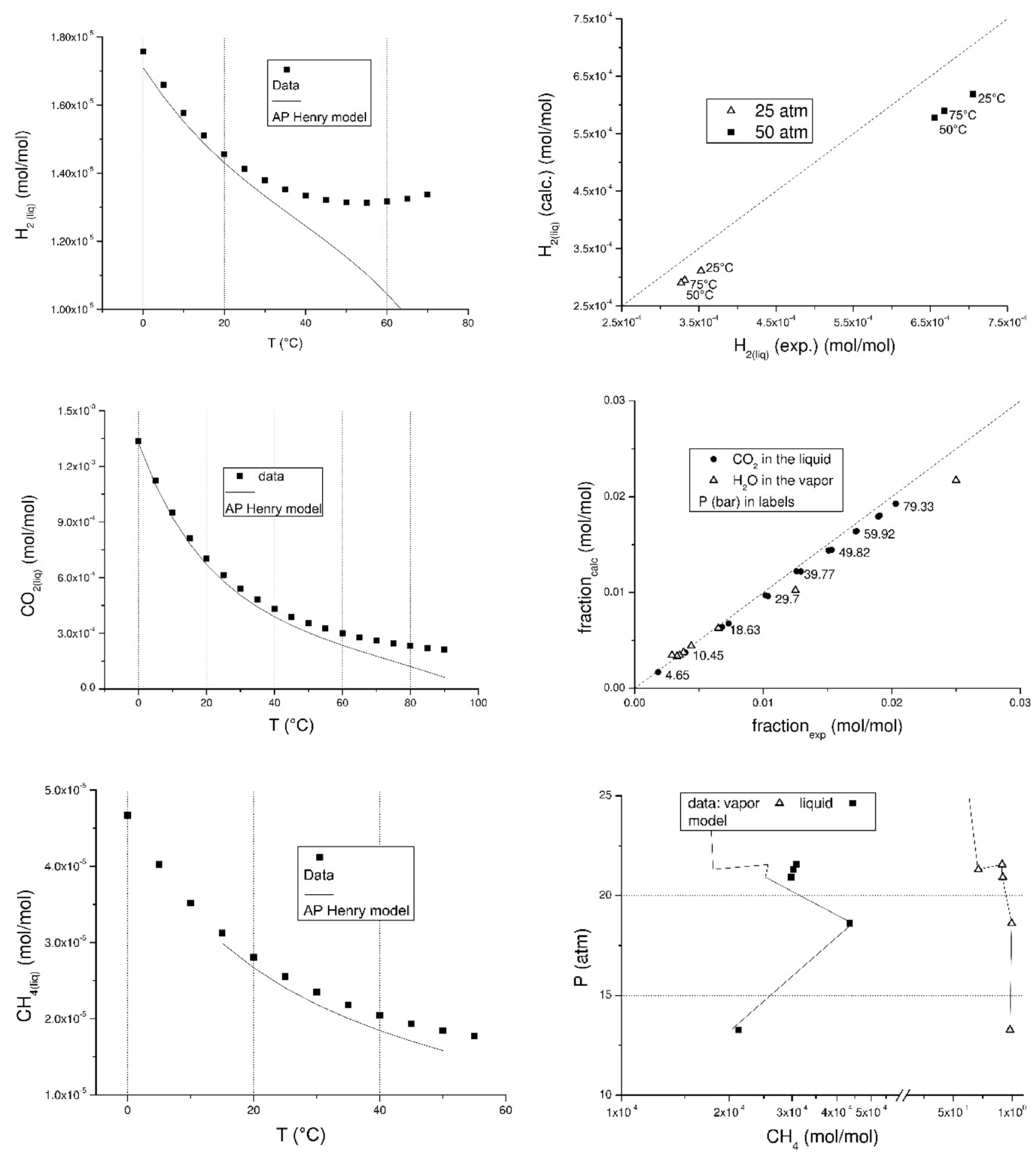

Fig. 2 Capability of the library models to reproduce the solubility of (from top): $\mathrm{H}_{2}$ (atmospheric-high pressure), $\mathrm{CO}_{2}$ and $\mathrm{CH}_{4}$ in water

the catalytic bed, the second part constitutes the heating stream of a plug-flow reactor;

- the first catalytic bed is supposed to 'end' where the outlet process and thermal fluid temperatures become closer than $300{ }^{\circ} \mathrm{C}$, so another virtual catalytic bed is added to intercept the third hot flues crossflow still at $1000{ }^{\circ} \mathrm{C}$. It is deemed that this twofold bed arrangement and threefold flues partition is a reasonable representation of the radiative section: the heat exchange 


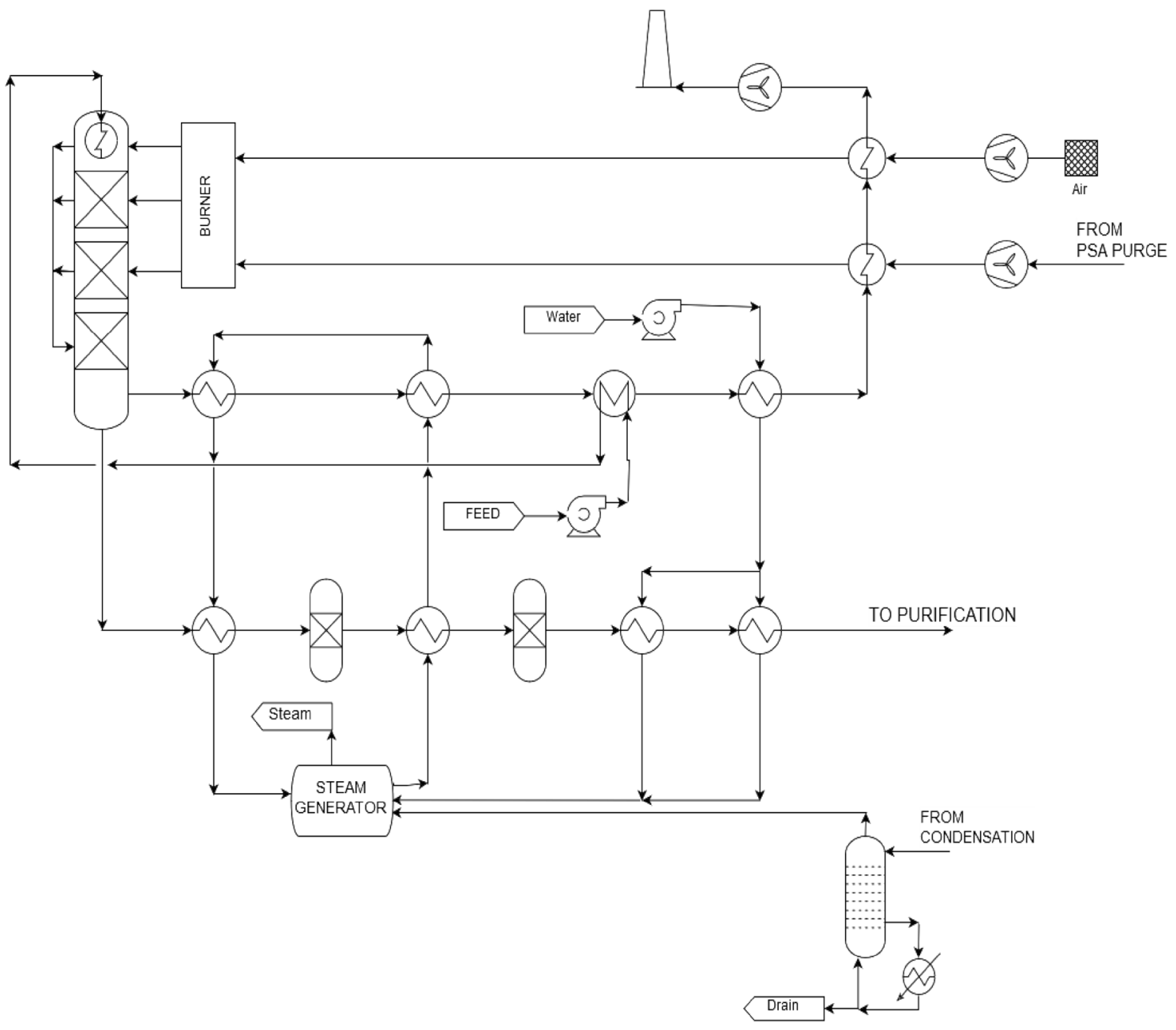

Fig. 3 PFD of the reforming section. PSA pressure swing adsorption

coefficient for this part is conservatively set to $30 \mathrm{~W} /$ $\mathrm{m}^{2}{ }^{\circ} \mathrm{C}$;

- the convective section is modelled via a single plugflow-reactor heated by a single flue stream, with a heat exchange coefficient of $15 \mathrm{~W} / \mathrm{m}^{2}{ }^{\circ} \mathrm{C}$.

The final (and most important) water-gas shift section is designed around $250{ }^{\circ} \mathrm{C}$, resorting to a kinetic expression available in the literature. After this step, the water still in excess can be condensed in one or two steps. The second strategy is convenient if the second separator works at higher pressures, and it is adopted here because pressures of 15-20 bar are more effective when $\mathrm{CO}_{2}$ is to be absorbed in basic aqueous solutions.

The carbon dioxide treatment module is based on the use of aqueous methyl diethanolamine (MDEA), $1.7 \mathrm{~mol}$ per mole of $\mathrm{CO}_{2}$, and a $3 \%$ volumetric fraction of carbon dioxide is allowed in the output stream [130], because most adsorption beds as the one foreseen downstream can actually capture also this gas. In both cases, anyway, the equilibrium condition at the condenser of the stripper makes a non-negligible amount of water to be lost with the carbon dioxide vent (3-4 wt\%) and the circuit between the columns is actually calculated with a continuous makeup in the low pressure side, just upstream the charging pump.

The pressure-swing purification part is accounted for after the results reported on multi-layer adsorption beds capable of trapping different gases [131, 132]. The purge stream is not recycled to recover the hydrogen [128], but routed to the burner. This approach is based on the following considerations:

- though hydrogen is a valuable building block, its use as a fuel is nearly as important;

- being the reforming reaction globally endothermic, recycling about the $30 \%$ of the produced hydrogen as a fuel keeps it within the process balances and also the 


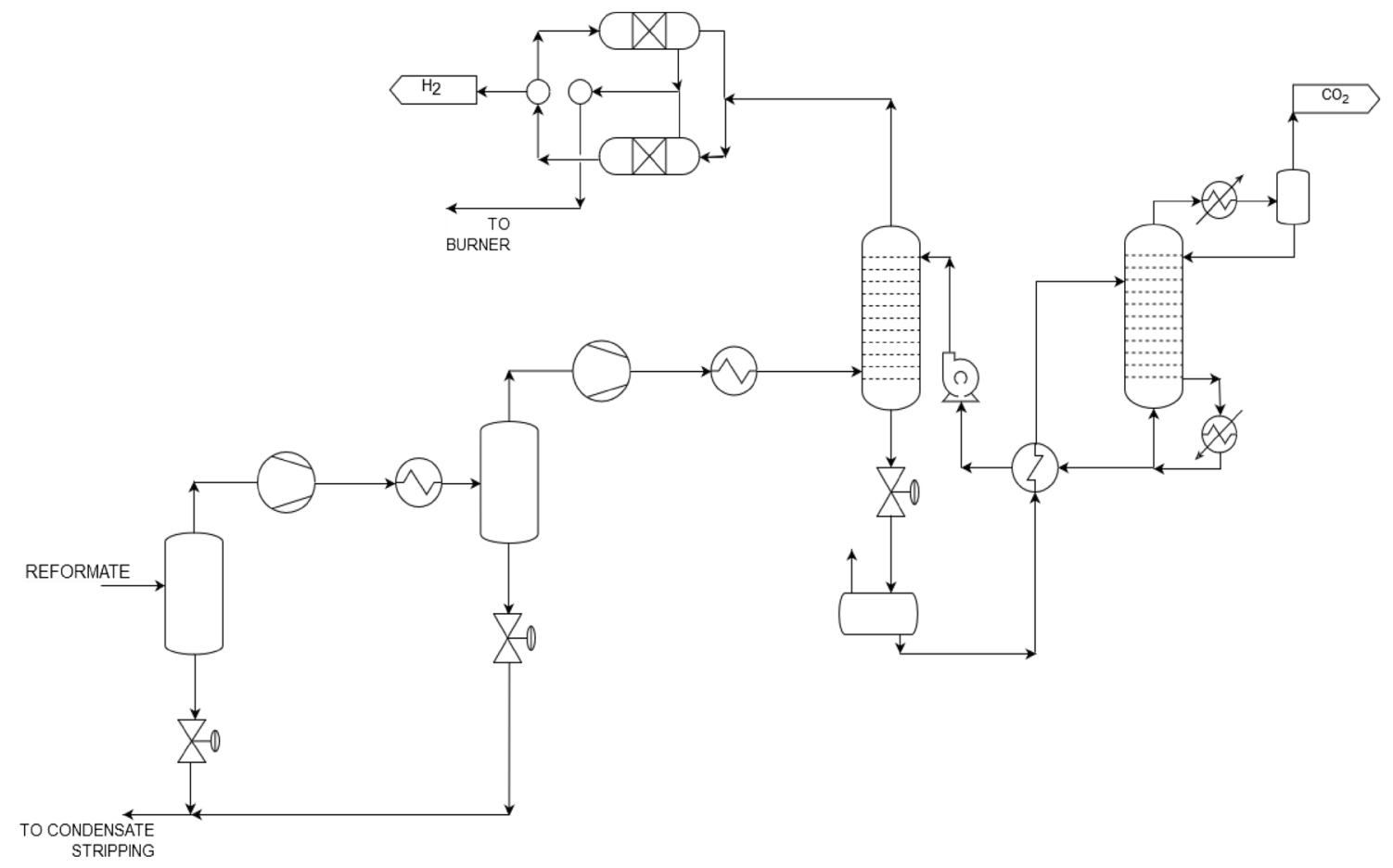

Fig. 4 PFD of the reformate purification

appreciable residual quantity of methane is turned into a fuel rather than a byproduct;

- this option leads to the design of a closed process, that does not rely neither on external fuel gas or azeotropic ethanol while it can exploit as desired a diluted inexpensive bioethanol, depending on the context mixture, it is worthwhile to study also a stand-alone version of the process.

Notice that, according to the reviewed references, also large quantities of $\mathrm{CO}_{2}$ can be treated via a pressure-swing apparatus relying on the same (or very similar) solids that entrap methane and carbon monoxide. The preliminary design has been devised in this way. A dedicated and selective purification section makes $\mathrm{CO}_{2}$ available for re-utilization or capture purposes. The delay in hydrogen production with respect to methane formation (due to the used reaction network) appears clearly in Fig. 5a, leaving to the last reformer stage the task to switch the ratio between the two species, with almost full conversion of the formed methane. In particular, Fig. 3, from left to right reports three catalytic packed bed reactors, the former for reforming (thermally sustained by a burner), the two high and low temperature water gas shift steps. In our previous investigations [79, 132, 133], the further purification was carried out by selective methanation of $\mathrm{CO}$, to achieve a residual 20 ppm amount. Here a new route was explored using a PSA system and an amine scrubbing module for the recovery of pure $\mathrm{CO}_{2}$, as detailed in Fig. 4 .

The conversion and thermal profile in the reforming reactor are detailed in Fig. 5, as well as the composition of the gas outflowing from each stage is detailed in Fig. 6a. Finally, Fig. $6 \mathrm{~b}$ details the duty needed for each stage. Besides the heat duty to the reactor, significant contribution is due to the condensation step, which needs compression of a large flowrate of gases (prodromal also to $\mathrm{CO}_{2}$ removal and PSA) and for the $\mathrm{CO}_{2}$ absorption unit, in particular for the regeneration of the amine.

\subsection{Energy Recovery}

The reformate that cools down to the condenser temperature (chosen slightly above $80^{\circ} \mathrm{C}$ ) and the burner flues exiting the reformer still contain some thermal energy that is partly used to pre-heat the feed and partly to produce low pressure steam. In principle, the feed heating stages depends on how the diluted ethanol is actually provided:

(1) as base case, it is supposed to start from a mildly preheated $\left(50^{\circ} \mathrm{C}\right)$ hydro-alcoholic mixture at the stoichiometric ratio, charged at the process pressure; this working point can be taken as reference to consider at least other two options [134-136]; 

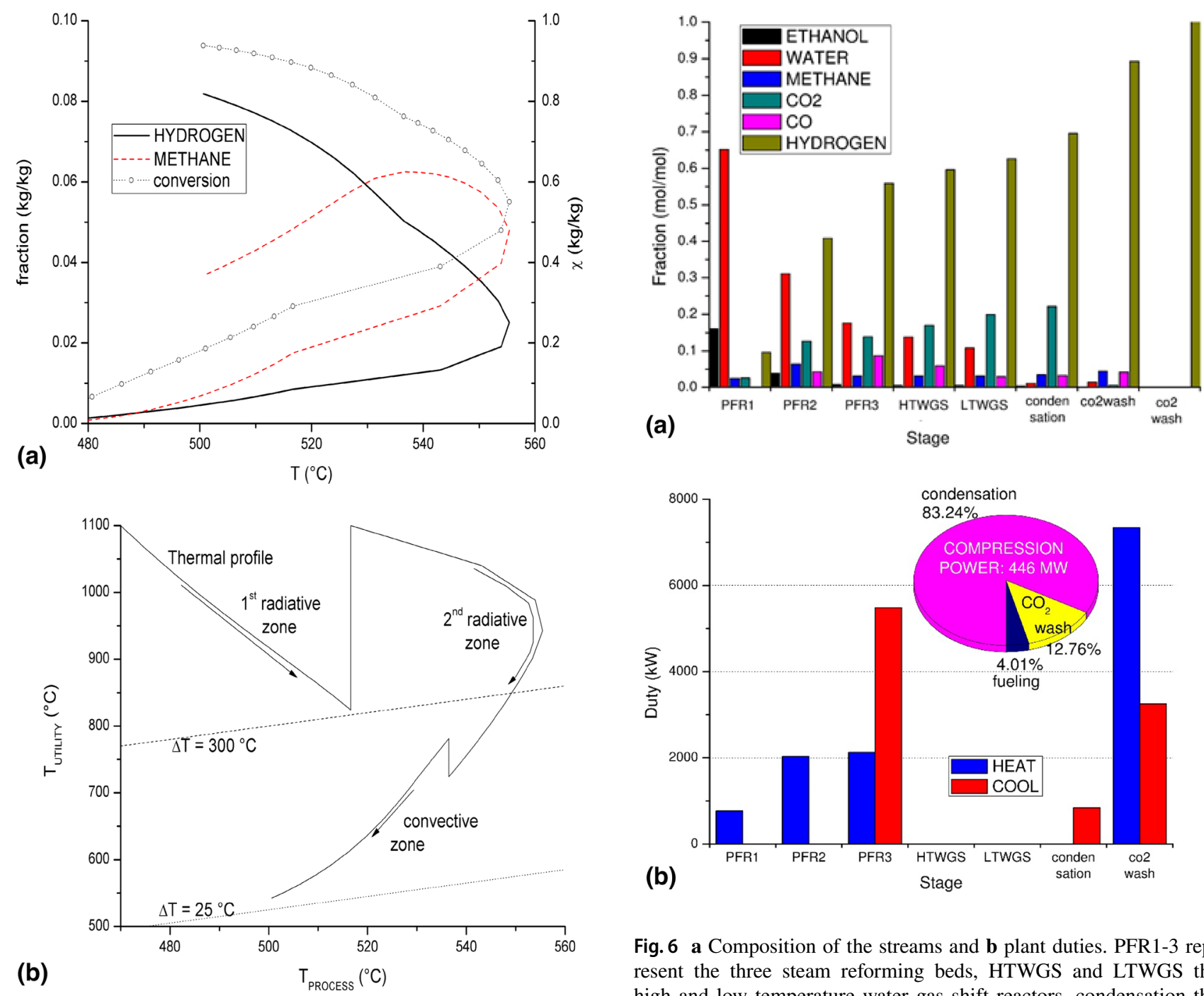

Fig. 6 a Composition of the streams and b plant duties. PFR1-3 represent the three steam reforming beds, HTWGS and LTWGS the high and low temperature water gas shift reactors, condensation the unit for water discharge and $\mathrm{CO}_{2}$ wash the $\mathrm{CO}_{2}$ absorption unit with amines (and relative regeneration)

Fig. 5 a profile of the energy-carrying species and conversion in reformer; $\mathbf{b}$ temperature difference map between the reacting mixtures and the flues

(2) reboil a fermentation broth up to the desired ethanol concentration and route it to the second feed heater;

(3) distillate azeotropic ethanol and mix it with the steam produced by the plant.

The water used to raise steam could belong to a closed cycle. If, instead, an open cycle should be designed, then there would be at least three different entry-levels for water into the system, according to what described above:

(a) as base case, fresh water enters the process and is mixed to the process condensate stripped from the dissolved gases;

(b) in this case the additional water could come from the bottoms of the wine boiler, but another pre-treatment would be needed;

(c) in this case the water could enter the system first in the auxiliary steam section, then be used as process feed to dilute the azeotrope.

The heat-recovering utilities have been designed after reviewing and adapting the already cited process layouts. Except for the ethanol/water feeding sections, subject to further optimization according to the above sketched criteria, the main thermal and power balances for the base case are summarized in the Fig. $6 \mathrm{~b}$.

The basic Pinch Analysis, restricted to the process streams only, is reported in Fig. 7. It is possible to see that, even at the process pressure, the dew point of the reformate is below the temperature level requested in the MDEA 

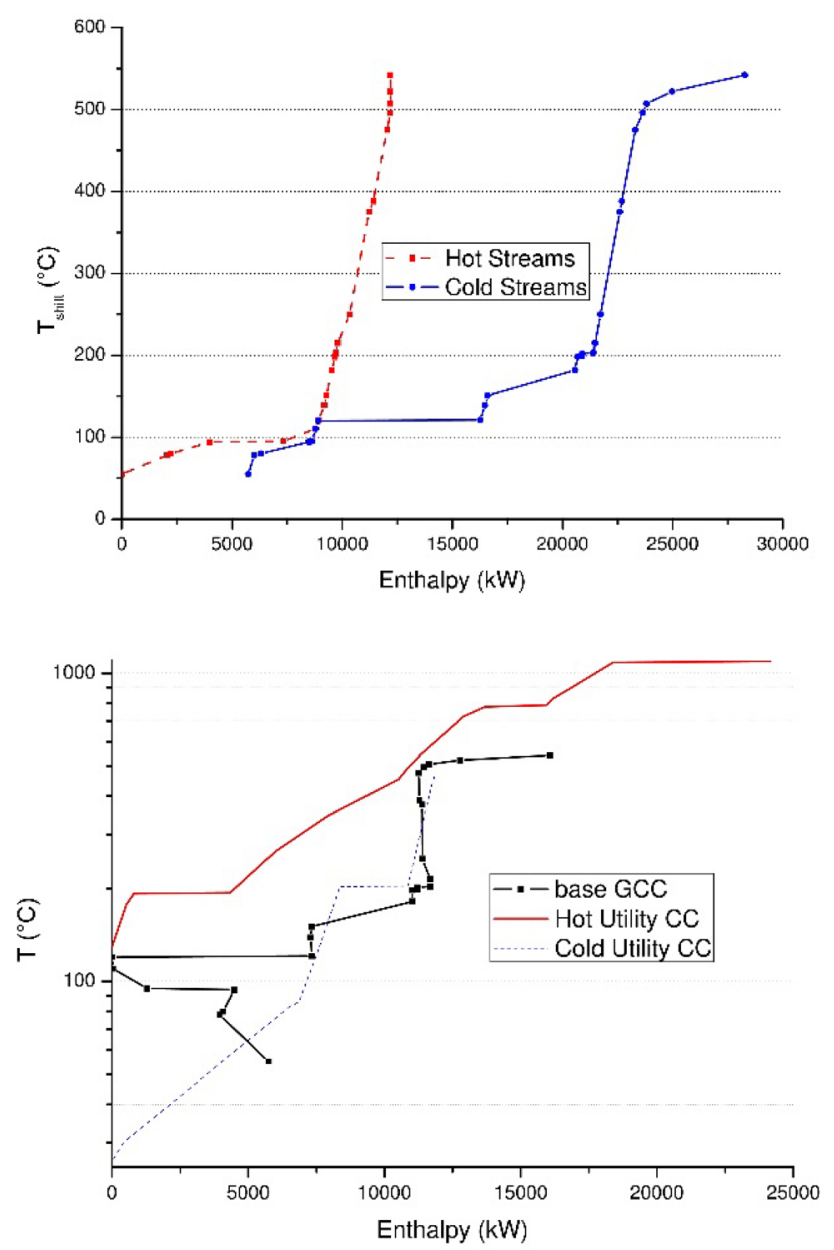

Fig. 7 Composite curves (CC) and Grand-Composite curve (GCC) for the process. The y-scale reports the shifted temperature

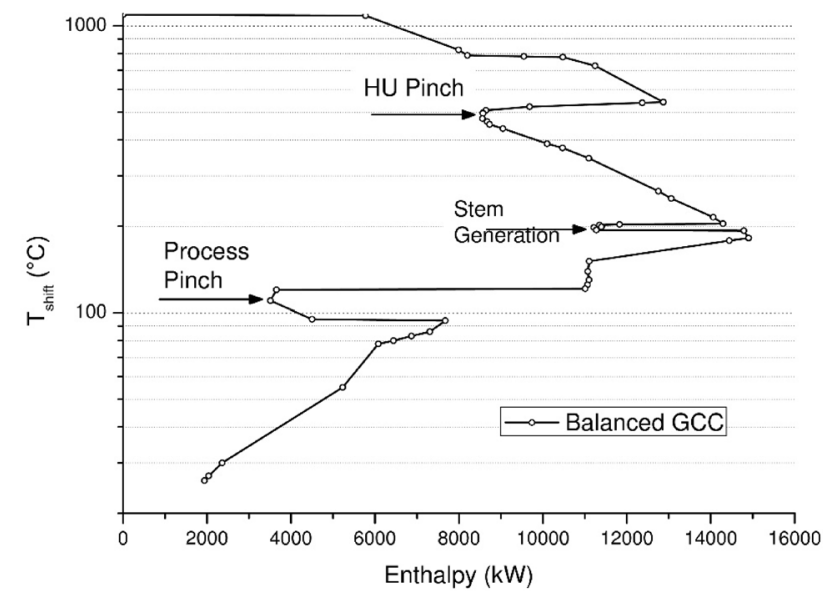

Fig. 8 Grand-Composite curve (GCC) for the process plus utilities after matching according to the pinch analysis. $H U$ hot utility stripper reboiler, leading to the poor overlap of the hot and cold composite curves (HCC and CCC). The choice of burning part of the hydrogen to supply the reaction energy leads naturally to the coupling of a Hot Utility profile (as indicated in the same graph), following the criterion of setting a utility pinch at the top kink of the grand composite curve (GCC, Fig. 8). The excess heat carried by the hot flues is spent rising steam at 15 bar $\left(195-198{ }^{\circ} \mathrm{C}\right)$, which brings to the curved shape of the hot curve below $430{ }^{\circ} \mathrm{C}$. The analysis lets foresee, anyway, at least two options for further energy recovery: lowering the highest flue temperature (e.g. by adding over-stoichiometric air) and/or rising more steam.

Table 2 highlights the main thermal parameters of the process and the process plus utilities. Notice that the final heat sink foreseen is atmospheric air. It is visible that a significant reduction of the foreseen use of hot and cold utilities is achieved after matching hot and cold streams according to the results of the pinch analysis.

\subsection{Distributed Heat and Power Cogeneration}

The main layout difference between the large-scale reforming and the micro-scale hydrogen production are [79, 133]:

- only $\mathrm{CO}$ must be removed but not $\mathrm{CO}_{2}$, then just a methanation reactor is foreseen upstream the water condenser to allow $\mathrm{CO}$ concentration down to $20 \mathrm{ppm}$. This unit can be discarded if high temperature PEMFC are used. Water condensation is anyway compulsory because the fuel cell would be flooded by excess water [137];

- the fuel to heat the reformer is extracted before the FC, then the system is intrinsically stable (in terms of global power output), because the electric power (hydrogen to the cell) and the thermal one (hydrogen to the burner) are dependent [78];

- the residual heat recovery is carried out in a series of blocks that simulate a common household heating system: since the quantity of ethanol needed to provide the standard electrical supply (i.e. $70 \mathrm{~mol} / \mathrm{h}$ of alcohol diluted with $350 \mathrm{~mol} / \mathrm{h}$ of water, that exceed the nominal $5 \mathrm{~kW}_{\text {electric }}$ target and leave a margin for fuel cell efficiencies possibly lower than 50\%) cannot cover, at the same time, also the installed thermal need (usually up to $20-25 \mathrm{~kW}_{\text {thermal }}$ for burners with hot convective flue flow), the calculation is solved dynamically exploiting the fact that most of the time the two kinds of appliances do not deliver their target power simultaneously.

Referring to the scheme in Fig. 9, the reforming system is represented in the lower section, while the house-heating system is drawn in the upper part, but only for its steadystate functioning part (i.e. the production of hot water to feed the radiators). 
Table 2 Main energetic parameters of the simulation cases

\begin{tabular}{lllrrrr}
\hline Case & $\begin{array}{l}\text { Overall } \\
\Delta \mathrm{T}\left({ }^{\circ} \mathrm{C}\right)\end{array}$ & $\mathrm{T}$ pinch $\left({ }^{\circ} \mathrm{C}\right)$ & $\mathrm{HU}(\mathrm{kW})$ & $\mathrm{CU}(\mathrm{kW})$ & Heat input $(\mathrm{kW})$ & $\begin{array}{l}\text { Heat Output } \\
(\mathrm{kW})\end{array}$ \\
\hline No matches & 10 & 121 & 16,100 & 5740 & 21,800 & 12,200 \\
Matches \& utilities & 10 & 111 & 0 & 1940 & 0 & - \\
\hline
\end{tabular}

$H U$ hot utility, $C U$ cold utility

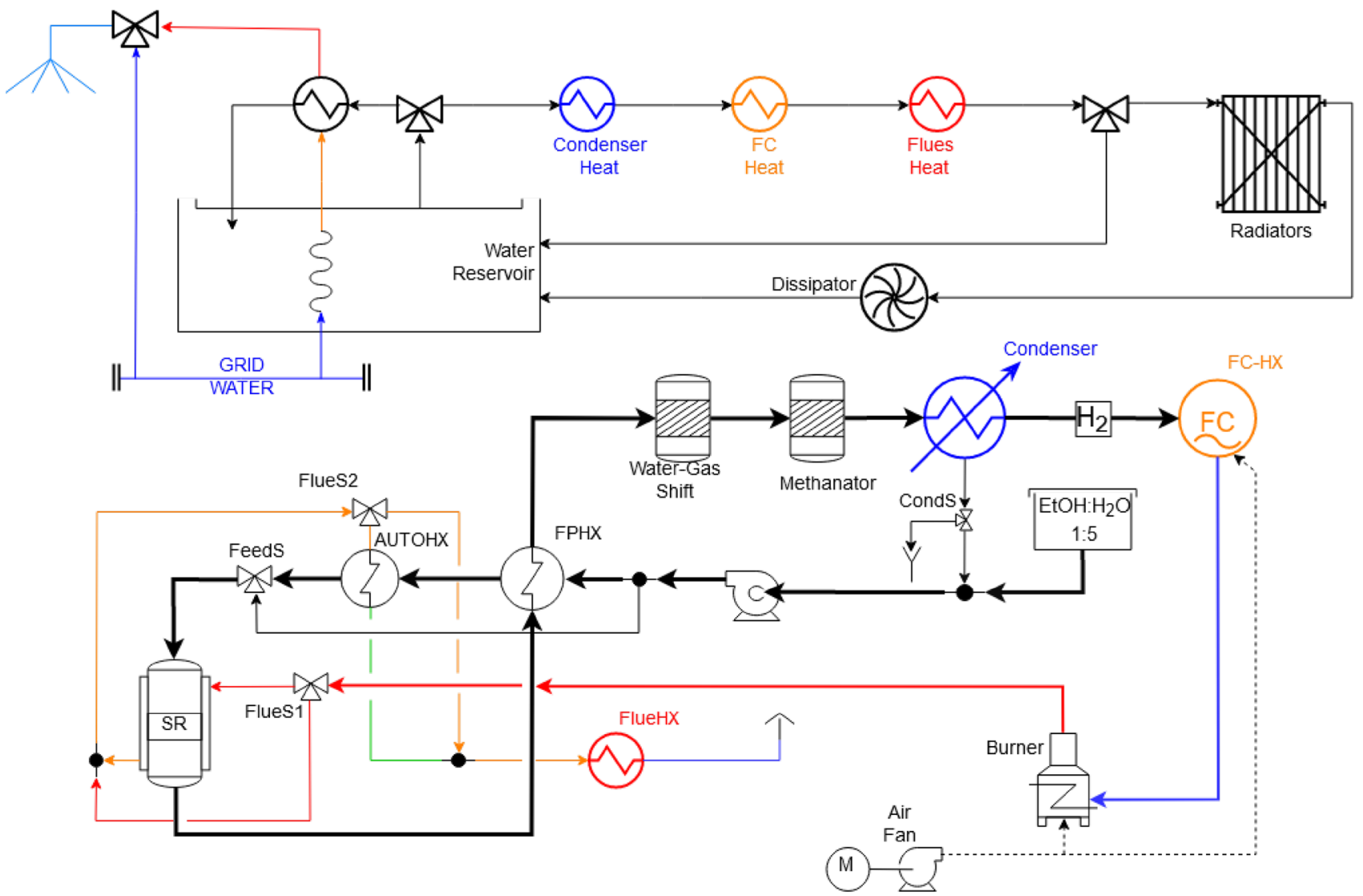

Fig. 9 Process flow diagram of a small-scale Heat \& Power Cogeneration unit. $S R$ steam reformer, $F C$ fuel cell

The key point of the material and energy recycle is the reformer behaviour, as is modelled rigorously via the reaction network presented above. In Fig. 10 it can be seen that right flowrate and temperature of the burned gas is crucial to avoid an anomalous temperature profile (with the given activation energy), that means in turn loss of the hydrogen output. Figure 10 exemplifies the thermal behaviour of the process and burner flue gas streams (used to heat up the reformer) along the catalyst bed. Good match is compulsory between the amount of reactants in the reforming process line and the one of reformate burned to thermally sustain the reformer, in order to avoid instability and consequent decreasing yield.

\subsection{Dynamic Energy Integration}

As already mentioned, the supply of sanitary water (up to 12 $\mathrm{L} / \mathrm{min}$ ) cannot be covered with the above mentioned feed, supposing to start from grid water at $5{ }^{\circ} \mathrm{C}$ to a high setpoint of $50{ }^{\circ} \mathrm{C}$ (see [82] and references therein), so a static heat reserve is put in order to store the power continuously discharged and not consumed. Also the steady-state operation, however, can shift from an enhanced electricity production to the delivery of more thermal power.

The working philosophy is as follows:

- the hydrogen usage at the FC determines the electric power and leaves more or less enthalpy after the burner; 


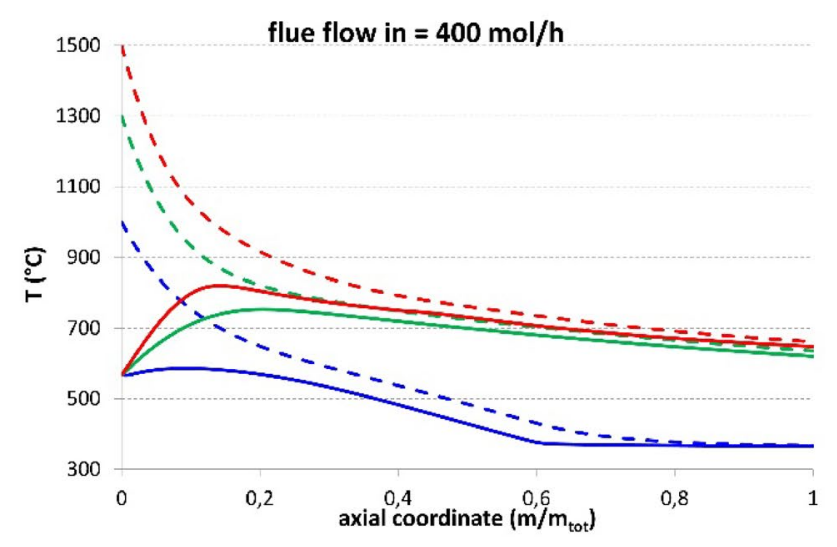

Fig. 10 Thermal behaviour of the reformer at 400 (left) and $600 \mathrm{~mol} / \mathrm{h}$ (right) of hot flues (feed: $420 \mathrm{~mol} / \mathrm{h}$ ). Solid lines: reformate-dashed lines: flues. Differently coloured curves refer to the

- according to the feed water content, some hot gas has to bypass the burner and/or the feed boiler to keep the reactor at the rated condition (around $500{ }^{\circ} \mathrm{C}$ );

- a reduced electricity production leaves then enough heat available, at the cell and flue gas heat exchangers, to meet the $6.5 \mathrm{~kW}$ to $70{ }^{\circ} \mathrm{C}$ wintertime utility requirement usually considered in most Northern Italy houses;

- when sanitary water is needed, the line passing though the dissipator is bypassed and all the heat available remains in the system: this set-up, coupled with the reservoir thermal inertia, keeps a milder sanitary set-point of $47-48^{\circ} \mathrm{C}$ for more than $30 \mathrm{~min}$.

The main results are reported in Figs. 11 and 12. Figure 11 reports for two cases of different $\mathrm{H}_{2}$ utilisation in the fuel cell, 50 or $80 \%$, the amount of heat available through different streams, i.e. from the FC itself, from the excess water discharged in the condenser and from waste flue gases. Different scenarios are compared (different colours) depending on the flow rate of water that can be recycled internally.

The same Fig. 11 also reports the profile of the sanitary water temperature available for the time lapse evidenced in abscissa, depending on the regulation of water supply. Details on this dynamic control scheme are available in the original reference.

Figure 12 summarises some data on the efficiency, whose total value may sum up to $60 \%$ with respect to the inlet ethanol feed.

\section{Conclusions}

Some of the most investigated processes for catalytic hydrogen production and for its recovery from biomass and biomass-derived substrates have been reviewed. Many efforts

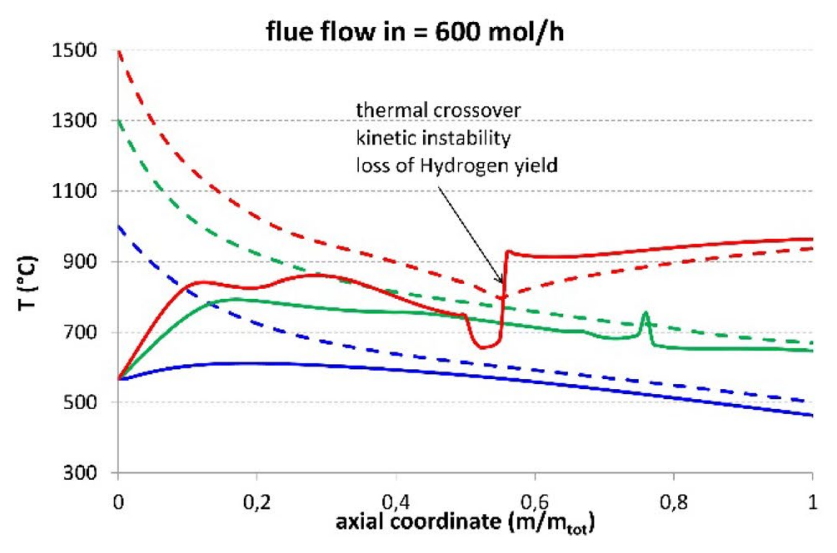

same process flow inlet temperature and variable heating flue gas temperatures (readable in the temperature scale)

in research and development are still needed in every case, depending on the level of maturity reached.

In many cases the open issues still rely on the development or optimisation of the catalytic material. For instance, in the case of APR, and more in general of the reforming of renewable substrates, transition metal catalysts have the advantage of low cost, good activity (even if under harsher conditions than noble metals), but are characterised by significant deactivation. This point is the main issue to be addressed in future investigations.

On the contrary, when attempting to develop photocatalytic routes for the valorisation of biomass-derived feedstocks, the targets of hydrogen productivity are not yet met, so catalyst development should rely mostly on optimising activity.

For the direct exploitation of biomass, the economy of scale suggests very large installations, which however do not fit the supply rate of biomass in most applications. The challenge is therefore the development of small decentralised plants that must be economically convenient. Some of the fractions produced, e.g. biooil or its aqueous fraction, may offer interesting options for catalytic valorisation through reforming. Yet, specific catalysts must developed to stably convert a widely variable substrate.

At this stage, for all the considered processes the robust knowledge of kinetics, reaction mechanism and process design plays a key role, and such topics should be early developed whenever possible to assess the real feasibility of the solution proposed.

Examining the SR of bioethanol as case history at sufficiently high TRL (demonstrative phase), the exergoenvironmental analysis shows that the main bottlenecks are related to exergy destruction in the burners, reformers and heat exchangers. Therefore, optimisation mainly refers to the integrated process, to better thermally integrate the 

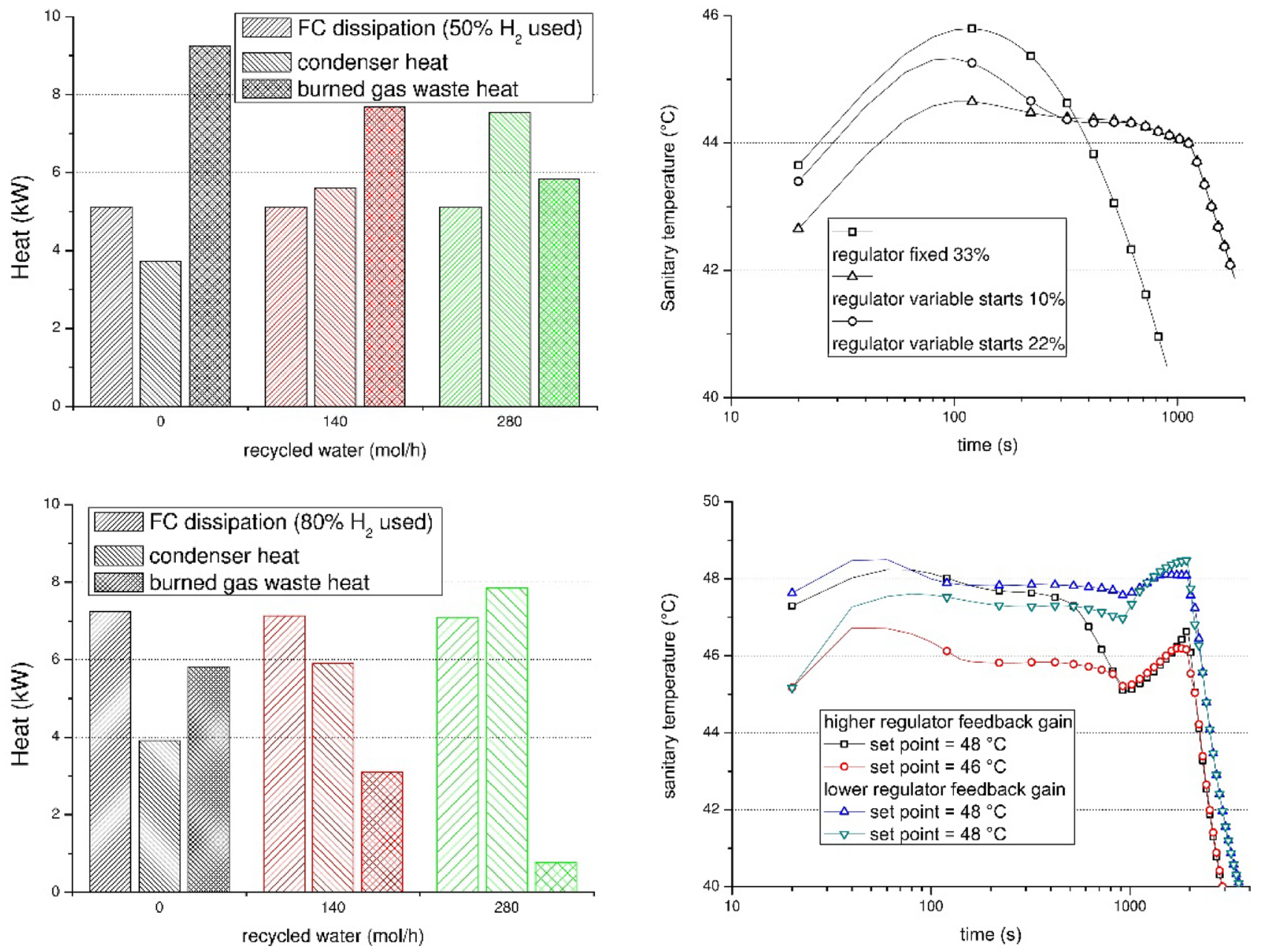

Fig. 11 From top: heat released at different ethanol:water ratios (40\% of burned gas to the reformer); adjustment of sanitary set point via timedependent water-mixing strategies. $F C$ fuel cell

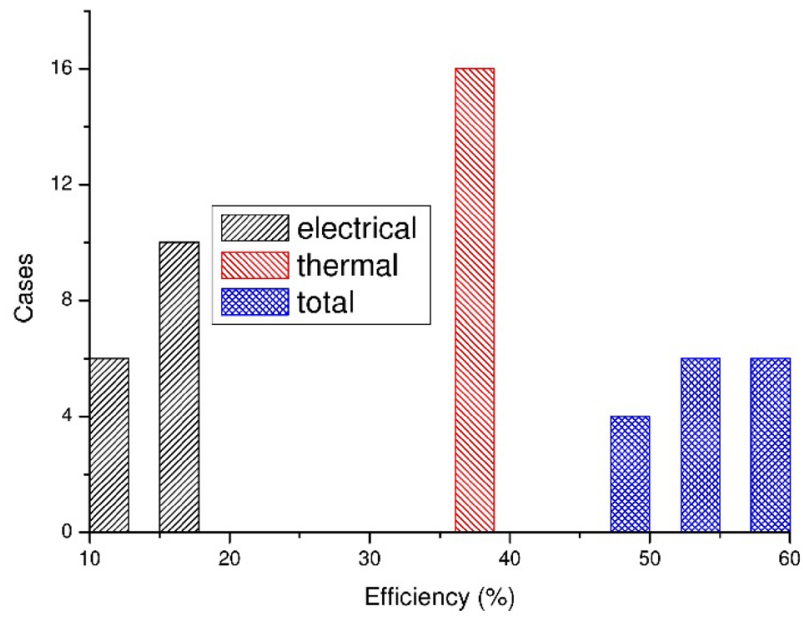

Fig. 12 Efficiency (\%) of all the tested working cases. The enthalpy content of ethanol has been set to $1370 \mathrm{~kJ} / \mathrm{mol}$ : the heat recovery is such as to maintain a nearly constant thermal efficiency different plant sections. In this light, efforts in catalyst development should be related in the decrease of operating temperature. Furthermore, the use of diluted bioethanol improves the water footprint of the process, together with the heat integration and energy efficiency of the system, but poses key questions on the reliability of the catalyst with possible impurities of the feed. Overall, the possibility to produce hydrogen through diluted hydroalcoholic solutions is demonstrated. This technology has been applied to the centralized production of hydrogen (big scale plant) and to the distributed co-generation of heat and power by using fuel cells. In this latter case, the time-to-time availability of sanitary water during winters has been considered dynamically, when demanding working conditions are yet present for heating, and demonstrated feasible.

Open Access This article is licensed under a Creative Commons Attribution 4.0 International License, which permits use, sharing, 
adaptation, distribution and reproduction in any medium or format, as long as you give appropriate credit to the original author(s) and the source, provide a link to the Creative Commons licence, and indicate if changes were made. The images or other third party material in this article are included in the article's Creative Commons licence, unless indicated otherwise in a credit line to the material. If material is not included in the article's Creative Commons licence and your intended use is not permitted by statutory regulation or exceeds the permitted use, you will need to obtain permission directly from the copyright holder. To view a copy of this licence, visit http://creativecommons. org/licenses/by/4.0/.

\section{References}

1. Yip HL, Srna A, Yuen ACY et al (2019) A review of hydrogen direct injection for internal combustion engines: towards carbonfree combustion. Appl Sci 9:4842. https://doi.org/10.3390/app92 24842

2. (2015) https://www.energy.gov/sites/prod/files/2015/11/f27/fcto_ fuel_cells_fact_sheet.pdf. Accessed Oct 2021

3. https://www.energy.gov/eere/fuelcells/fuel-cells

4. Ferraren-De Cagalitan DDT, Abundo MLS (2021) A review of biohydrogen production technology for application towards hydrogen fuel cells. Renew Sustain Energy Rev. https://doi.org/ 10.1016/J.RSER.2021.111413

5. Tzelepis S, Kavadias KA, Marnellos GE, Xydis G (2021) A review study on proton exchange membrane fuel cell electrochemical performance focusing on anode and cathode catalyst layer modelling at macroscopic level. Renew Sustain Energy Rev. https://doi.org/10.1016/J.RSER.2021.111543

6. Melo SP, Barke A, Cerdas F et al (2020) Sustainability assessment and engineering of emerging aircraft technologies-challenges, methods and tools. Sustainability (Switzerland). https:// doi.org/10.3390/su12145663

7. Savla N, Suman PS et al (2021) Techno-economical evaluation and life cycle assessment of microbial electrochemical systems: a review. Curr Res Green Sustain Chem. https://doi.org/10.1016/J. CRGSC.2021.100111

8. Mahian O, Mirzaie MR, Kasaeian A, Mousavi SH (2020) Exergy analysis in combined heat and power systems: a review. Energy Convers Manage 226:113467. https://doi.org/10.1016/J.ENCON MAN.2020.113467

9. Valera-Medina A, Amer-Hatem F, Azad AK et al (2021) Review on ammonia as a potential fuel: from synthesis to economics. Energy Fuels 35:6964-7029. https://doi.org/10.1021/acs.energ yfuels.0c03685

10. https://afdc.energy.gov/fuels/ethanol_fuel_basics.html. Accessed Oct 2021

11. Javaid R (2021) Catalytic hydrogen production, storage and application. Catalysts 11:12-13. https://doi.org/10.3390/catal 11070836

12. Kalamaras CM, Efstathiou AM (2013) Hydrogen production technologies: current state and future developments. Conf Pap Energy 2013:1-9. https://doi.org/10.1155/2013/690627

13. Panagiotopoulou P, Papadopoulou C, Matralis H, Verykios X (2014) Production of renewable hydrogen by reformation of biofuels. Wiley Interdiscip Rev Energy Environ 3:231-253. https:// doi.org/10.1002/wene.93

14. Baraj E, Ciahotný K, Hlinčík T (2021) The water gas shift reaction: catalysts and reaction mechanism. Fuel. https://doi.org/10. 1016/j.fuel.2020.119817

15. Nisbet EG, Dlugokencky EJ, Bousquet P (2014) Methane on the rise-again. Science 343:493-495. https://doi.org/10.1126/ SCIENCE. 1247828
16. Chen Y, Mu X, Luo X et al (2020) Catalytic conversion of methane at low temperatures: a critical review. Energ Technol. https:// doi.org/10.1002/ENTE.201900750

17. Zhang H, Sun Z, Hu YH (2021) Steam reforming of methane: Current states of catalyst design and process upgrading. Renew Sustain Energy Rev. https://doi.org/10.1016/J.RSER.2021. 111330

18. Adris AM, Pruden BB, Lim CJ, Grace JR (1996) On the reported attempts to radically improve the performance of the steam methane reforming reactor. Can J Chem Eng 74:177-186

19. Mehmeti A, Angelis-Dimakis A, Arampatzis G et al (2018) Life cycle assessment and water footprint of hydrogen production methods: from conventional to emerging technologies. Environments. https://doi.org/10.3390/environments5020000

20. Moreira R, Bimbela F, Gandía LM et al (2021) Oxidative steam reforming of glycerol. A review. Renew Sustain Energy Rev. https://doi.org/10.1016/J.RSER.2021.111299

21. Rossetti I, Biffi C, Tantardini GF et al (2012) $5 \mathrm{~kW} \mathrm{e}+5 \mathrm{~kW} \mathrm{t}$ reformer-PEMFC energy generator from bioethanol first data on the fuel processor from a demonstrative project. Int J Hydrogen Energy 37:8499-8504. https://doi.org/10.1016/j.ijhydene.2012. 02.095

22. Lee WJ, Li C, Prajitno H et al (2021) Recent trend in thermal catalytic low temperature $\mathrm{CO}_{2}$ methanation: a critical review. Catal Today 368:2-19. https://doi.org/10.1016/j.cattod.2020. 02.017

23. Rhodes C, Williams BP, King F, Hutchings GJ (2002) Promotion of $\mathrm{Fe}_{3} \mathrm{O}_{4} / \mathrm{Cr}_{2} \mathrm{O}_{3}$ high temperature water gas shift catalyst. Catal Commun 3:381-384

24. Alijani A, Irankhah A (2013) Medium-temperature shift catalysts for hydrogen purification in a single-stage reactor. Chem Eng Technol 36:209-219. https://doi.org/10.1002/ceat.201200151

25. Pal DB, Chand R, Upadhyay SN, Mishra PK (2018) Performance of water gas shift reaction catalysts: a review. Renew Sustain Energy Rev 93:549-565. https://doi.org/10.1016/J.RSER.2018. 05.003

26. Song C (2002) Fuel processing for low-temperature and hightemperature fuel cells: challenges, andopportunities for sustainable development in the 21st century. Catal Today 77:17-49

27. de Guido G, Compagnoni M, Pellegrini LA, Rossetti I (2018) Mature versus emerging technologies for $\mathrm{CO}_{2}$ capture in power plants: Key open issues in post-combustion amine scrubbing and in chemical looping combustion. Front Chem Sci Eng. https:// doi.org/10.1007/s11705-017-1698-Z

28. NREL www.nrel.gov/hydrogen/New Horizons For Hydrogen

29. Asadullah M, Ito SI, Kunimori K, Tomishige K (2002) Energy efficient production of hydrogen and syn- gas from biomass: development of low-temperature catalytic process for cellulose gasification. Environ Sci Technol 36:4476-4481

30. Yang K, Zhu N, Yuan T (2017) Analysis of optimum scale of biomass gasification combined cooling heating and power (CCHP) system based on life cycle assessment(LCA). Procedia Eng 205:145-152. https://doi.org/10.1016/j.proeng.2017.09.946

31. Wang S, Shan R, Gu J et al (2020) Pyrolysis municipal sludge char supported $\mathrm{Fe} / \mathrm{Ni}$ catalysts for catalytic reforming of tar model compound. Fuel. https://doi.org/10.1016/J.FUEL.2020. 118494

32. He L, Hu S, Yin X et al (2020) Promoting effects of Fe-Ni alloy on co-production of $\mathrm{H}_{2}$ and carbon nanotubes during steam reforming of biomass tar over Ni-Fe/ $\alpha-\mathrm{Al}_{2} \mathrm{O}_{3}$. Fuel. https://doi. org/10.1016/J.FUEL.2020.118116

33. Yoon SJ, Kim YK, Lee JG (2011) Catalytic oxidation of biomass tar over platinum and ruthenium catalysts. Ind Eng Chem Res 50:2445-2451. https://doi.org/10.1021/IE1020365

34. Gao N, Salisu J, Quan C, Williams P (2021) Modified nickelbased catalysts for improved steam reforming of biomass tar: a 
critical review. Renew Sustain Energy Rev. https://doi.org/10. 1016/J.RSER.2021.111023

35. Gao N, Chen K, Lai X, Quan C (2021) Catalytic steam reforming of real tar under high-efficiency Ni/USY catalyst for $\mathrm{H}_{2}$ production. Fuel. https://doi.org/10.1016/J.FUEL.2021.121676

36. Tanksale A, Beltramini JN, Lu GQM (2010) A review of catalytic hydrogen production processes from biomass. Renew Sustain Energy Rev 14:166-182. https://doi.org/10.1016/j.rser.2009.08. 010

37. Nachenius RW, Ronsse F, Venderbosch RH, Prins W (2013) Biomass pyrolysis. Adv Chem Eng 42:75-139. https://doi.org/10. 1016/B978-0-12-386505-2.00002-X

38. Wang D, Czernik S, Chornet E (1998) Production of hydrogen from biomass by catalytic steam reforming of fast pyrolysis oils. Energy Fuels 12:19-24

39. Czernik S, Evans R, French R (2007) Hydrogen from biomassproduction by steam reforming of biomass pyrolysis oil. Catal Today 129:265-268

40. Czernik S, French R, Feik C, Chornet E (2002) Hydrogen by catalytic steam reforming of liquid byproducts from biomass thermoconversion processes. Ind Eng Chem Res 41:4209-4215

41. Searcy E, Hess JR, Tumuluru J et al (2014) Optimization of biomass transport and logistics. In: Lecture Notes in Energy (LNEN, volume 17). pp 103-123

42. Bakhtyari A, Makarem MA, Rahimpour MR (2019) Hydrogen production through pyrolysis. Fuel cells and hydrogen production. Springer, New York, pp 947-973

43. He L, Yang J, Chen D (2013) Hydrogen from biomass: advances in thermochemical processes. Renew Hydrogen Technol Prod Purif Storage Appl Saf. https://doi.org/10.1016/B978-0-44456352-1.00006-4

44. Davda R, Shabaker J, Huber G et al (2003) Aqueous-phase reforming ofethylene glycol on silica-supported metal catalysts. Appl Catal B 43:13-26

45. Suen N-T, Hung S-F, Quan Q et al (2017) Electrocatalysis for the oxygen evolution reaction: recent development and future perspectives. Chem Soc Rev 46:337-365

46. Wang S, Lu A, Zhong CJ (2021) Hydrogen production from water electrolysis: role of catalysts. Nano Convergence. https:// doi.org/10.1186/s40580-021-00254-x

47. Vrubel H, Hu X (2012) Molybdenum boride and carbide catalyze hydrogen evolution in both acidic and basic solutions. Angew Chem Int Ed 51:12703-12706

48. Bahadori E, Ramis G, Zanardo D et al (2020) Photoreforming of glucose over $\mathrm{CuO} / \mathrm{TiO}_{2}$. Catalysts 10:477. https://doi.org/10. 3390/catal10050477

49. Ramis G, Bahadori E, Rossetti I (2019) Photoreactors design for hydrogen production. Chem Eng Trans 74:481-486. https://doi. org/10.3303/CET1974081

50. Ramis G, Bahadori E, Rossetti I (2021) Design of efficient photocatalytic processes for the production of hydrogen from biomass derived substrates. Int J H2 Energy 46:12105-12116. https://doi. org/10.1016/j.ijhydene.2020.02.192

51. Contreras JL, Salmones J, Colín-Luna JA et al (2014) Catalysts for $\mathrm{H} 2$ production using the ethanol steam reforming (a review). Int J Hydrogen Energy 39:18835-18853. https://doi.org/10. 1016/J.IJHYDENE.2014.08.072

52. Mekhilef S, Saidur R, Safari A (2012) Comparative study of different fuel cell technologies. Renew Sustain Energy Rev 16:981-989. https://doi.org/10.1016/J.RSER.2011.09.020

53. Song H (2012) Catalytic hydrogen production from bioethanol. Bioethanol. https://doi.org/10.5772/20396

54. Sanchez N, Ruiz R, Hacker V, Cobo M (2020) Impact of bioethanol impurities on steam reforming for hydrogen production: a review. Int J Hydrogen Energy 45:11923-11942. https://doi.org/ 10.1016/J.IJHYDENE.2020.02.159
55. Posada JA, Patel AD, Roes A et al (2013) Potential of bioethanol as a chemical building block for biorefineries: preliminary sustainability assessment of 12 bioethanol-based products. Bioresour Technol 135:490-499. https://doi.org/10.1016/J.BIORT ECH.2012.09.058

56. Malode SJ, Prabhu KK, Mascarenhas RJ et al (2021) Recent advances and viability in biofuel production. Energy Convers Manage: X 10:100070. https://doi.org/10.1016/j.ecmx.2020. 100070

57. Ayodele BV, Mustapa SI, Tuan Abdullah TAR, Bin SSF (2019) A mini-review on hydrogen-rich syngas production by thermocatalytic and bioconversion of biomass and its environmental implications. Front Energy Res 7:1-6. https://doi.org/10.3389/ fenrg.2019.00118

58. Rossetti I, Gallo A, DalSanto V et al (2013) Nickel catalysts supported over $\mathrm{TiO}_{2}, \mathrm{SiO}_{2}$ and $\mathrm{ZrO}_{2}$ for the steam reforming of glycerol. ChemCatChem 5:294-306. https://doi.org/10.1002/ cctc. 201200481

59. Conte F, Esposito S, Dal Santo V et al (2021) Flame pyrolysis synthesis of mixed oxides for glycerol steam reforming. Materials. https://doi.org/10.3390/ma14030652

60. Villa A, Gaiassi A, Rossetti I et al (2010) $\mathrm{Au}$ on $\mathrm{MgAl}_{2} \mathrm{O}_{4}$ spinels: the effect of support surface properties in glycerol oxidation. J Catal 275:108-116. https://doi.org/10.1016/j.jcat.2010. 07.022

61. Balat M, Balat M (2009) Political, economic and environmental impacts of biomass-based hydrogen. Int J Hydrogen Energy 34:3589-3603

62. Bornapour M, Hooshmand RA, Khodabakhshian A, Parastegari M (2017) Optimal stochastic coordinated scheduling of proton exchange membrane fuel cell-combined heat and power, wind and photovoltaic units in micro grids considering hydrogen storage. Appl Energy 202:308-322. https://doi.org/10.1016/j. energy.2016.10.072

63. Compagnoni M, Mostafavi E, Tripodi A et al (2017) Technoeconomic analysis of a bioethanol to hydrogen centralized plant. Energy Fuels 31:12988-12996. https://doi.org/10.1021/ acs.energyfuels.7b02434

64. Compagnoni M, Tripodi A, Mostafavi E et al (2017) Hydrogen production by steam reforming of bio-ethanol: Process design and economic assessment. In: DGMK Tagungsbericht

65. Dahman Y, Syed K, Begum S et al (2019) Biofuels: their characteristics and analysis. In: Verma D, Fortunati E, Zhang $X$ (eds) Biomass, biopolymer-based materials, and bioenergy: construction, biomedical, and other industrial applications. Elsevier, New York, pp 277-325. https://doi.org/10.1016/ B978-0-08-102426-3.00014-X

66. Sindhu R, Binod P, Pandey A et al (2019) Biofuel production from biomass: toward sustainable development. In: Kumar S, Kumar R, Pandey A (eds) Current developments in biotechnology and bioengineering: waste treatment processes for energy generation. Elsevier, New York, pp 79-92. https://doi.org/10. 1016/B978-0-444-64083-3.00005-1

67. Chakraborty R, Mukhopadhyay P (2020) Green Fuel Blending: A Pollution Reduction Approach. In: Hashmi S, Choudhury IA (eds) Encyclopedia of Renewable and Sustainable Materials. Elsevier, New York, pp 487-500. https://doi.org/10.1016/ B978-0-12-803581-8.11019-7

68. Palma V, Ruocco C, Cortese M, Martino M (2020) Bioalcohol reforming: an overview of the recent advances for the enhancement of catalyst stability. Catalysts 10:665. https://doi.org/10. 3390/catal10060665

69. Palanisamy A, Soundarrajan N, Ramasamy G (2021) Analysis on production of bioethanol for hydrogen generation. Environ Sci Pollut Res. https://doi.org/10.1007/s11356-021-14554-6 
70. Compagnoni M, Tripodi A, Di Michele A et al (2017) Low temperature ethanol steam reforming for process intensification: new $\mathrm{Ni} / \mathrm{MxO}-\mathrm{ZrO}_{2}$ active and stable catalysts prepared by flame spray pyrolysis. Int J Hydrogen Energy 42:28193-28213. https://doi.org/10.1016/j.ijhydene.2017.09.123

71. Rossetti I, Biffi C, Bianchi CL et al (2012) Ni/SiO${ }_{2}$ and $\mathrm{Ni} /$ $\mathrm{ZrO}_{2}$ catalysts for the steam reforming of ethanol. Appl Catal B 117-118:384-396. https://doi.org/10.1016/j.apcatb.2012.02. 006

72. Di Michele A, Dell'Angelo A, Tripodi A et al (2019) Steam reforming of ethanol over $\mathrm{Ni} / \mathrm{MgAl}_{2} \mathrm{O}_{4}$ catalysts. Int J Hydrogen Energy. https://doi.org/10.1016/j.ijhydene.2018.11.048

73. Compagnoni M, Lasso J, Di Michele A, Rossetti I (2016) Flamepyrolysis-prepared catalysts for the steam reforming of ethanol. Catal Sci Technol 6:6257. https://doi.org/10.1039/c5cy01958c

74. Rossetti I, Lasso J, Finocchio E et al (2014) ${ }_{\mathrm{TiO} 2}$-supported catalysts for the steam reforming of ethanol. Appl Catal A 477:4253. https://doi.org/10.1016/j.apcata.2014.03.004

75. Rossetti I, Lasso J, Nichele V et al (2014) Silica and zirconia supported catalysts for the low-temperature ethanol steam reforming. Appl Catal B 150-151:257-267. https://doi.org/10.1016/j.apcatb. 2013.12.012

76. Tripodi A, Compagnoni M, Rossetti I (2016) Kinetic modelling and reactor simulation for ethanol steam reforming. ChemCatChem 8:3804-3813

77. Compagnoni M, Tripodi A, Rossetti I (2017) Parametric study and kinetic testing for ethanol steam refroming. Appl Catal B: Environ 203:899-909

78. Rossetti I, Compagnoni M, Torli M (2015) Process simulation and optimization of $\mathrm{H}_{2}$ production from ethanol steam reforming and its use in fuel cells. 2. Process analysis and optimization. Chem Eng J 281:1036-1044. https://doi.org/10.1016/j.cej.2015. 08.045

79. Tripodi A, Compagnoni M, Ramis G, Rossetti I (2017) Process simulation of hydrogen production by steam reforming of diluted bioethanol solutions: Effect of operating parameters on electrical and thermal cogeneration by using fuel cells. Int J Hydrogen Energy. https://doi.org/10.1016/j.ijhydene.2017.04.056

80. Tripodi A, Compagnoni M, Bahadori E et al (2018) Process intensification by exploiting diluted 2 nd generation bio-ethanol in the low-temperature steam reforming process. Top Catal. https://doi.org/10.1007/s11244-018-1002-6

81. Tripodi A, Pizzonia A, Bahadori E, Rossetti I (2018) Integrated plant layout for heat and power cogeneration from diluted bioethanol. ACS Sustain Chem Eng. https://doi.org/10.1021/acssu schemeng.8b00144

82. Tripodi A, Bahadori E, Ramis G, Rossetti I (2019) Feasibility assessment, process design and dynamic simulation for cogeneration of heat and power by steam reforming of diluted bioethanol. Int J Hydrogen Energy 44:2-22. https://doi.org/10.1016/j.ijhyd ene.2018.02.122

83. Rossetti I, Tripodi A, Ramis G (2020) Hydrogen, ethylene and power production from bioethanol: ready for the renewable market? Int J Hydrogen Energy. https://doi.org/10.1016/j.ijhydene. 2019.07.201

84. Rossetti I, Biffi C, Forni L et al (2010) Integrated $5 \mathrm{kWe}+5 \mathrm{kWt}$ PEM-FC generator from bioethanol: a demonstrative project. In: ASME 2010 8th International Conference on Fuel Cell Science, Engineering and Technology, FUELCELL 2010. pp 465-471

85. Seyam S, Dincer I, Agelin-chaab M (2021) Investigation of potential fuels for hybrid molten carbonate fuel cell-based aircraft propulsion systems. Energy Fuels 35:10156-10168. https:// doi.org/10.1021/acs.energyfuels.1c00915

86. de Souza TAZ, Rocha DHD, Julio AAV et al (2021) Exergoenvironmental assessment of hydrogen water footprint via steam reforming in Brazil. J Clean Prod 311:127577. https://doi.org/10. 1016/J.JCLEPRO.2021.127577

87. Izurieta EM, Pedernera MN, López E (2019) Study of a thermally integrated parallel plates reactor for hydrogen production. Chem Eng Sci 196:344-353. https://doi.org/10.1016/J.CES.2018.11. 011

88. Izurieta EM, Adrover ME, Pedernera MN, Lópezlópez E (2018) Ethanol processor design for hydrogen production. Kinet Anal Process Integr. https://doi.org/10.1021/acs.iecr.8b02324

89. Spallina V, Matturro G, Ruocco C et al (2018) Direct route from ethanol to pure hydrogen through autothermal reforming in a membrane reactor: experimental demonstration, reactor modelling and design. Energy 143:666-681. https://doi.org/10.1016/J. ENERGY.2017.11.031

90. Moraes TS, Cozendey da Silva HN, Zotes LP et al (2019) A techno-economic evaluation of the hydrogen production for energy generation using an ethanol fuel processor. Int J Hydrogen Energy 44:21205-21219. https://doi.org/10.1016/J.IJHYDENE. 2019.06.182

91. Kiani MR, Meshksar M, Makarem MA, Rahimpour E (2021) Catalytic membrane micro-reactors for fuel and biofuel processing: a mini review. Top Catal. https://doi.org/10.1007/ s11244-021-01505-1

92. Wang JH, Lee CS, Lin MC (2009) Mechanism of ethanol reforming: theoretical foundations. J Phys Chem C 113:66816688. https://doi.org/10.1021/jp810307h

93. Sutton JE, Panagiotopoulou P, Verykios XE, Vlachos DG (2013) Combined DFT, microkinetic, and experimental study of ethanol steam reforming on Pt. J Phys Chem C 117:46914706. https://doi.org/10.1021/jp312593u

94. Llera I, Mas V, Bergamini ML et al (2012) Bio-ethanol steam reforming on Ni based catalyst. Kinetic study. Chem Eng Sci 71:356-366. https://doi.org/10.1016/j.ces.2011.12.018

95. Graschinsky C, Laborde M, Amadeo N et al (2010) Ethanol steam reforming over $\mathrm{Rh}(1 \%) \mathrm{MgAl}_{2} \mathrm{O}_{4} / \mathrm{Al}_{2} \mathrm{O}_{3}$ : a kinetic study. Ind Eng Chem Res 49:12383-12389

96. Rossetti I, Compagnoni M, Finocchio E et al (2016) Syngas production via steam reforming of bioethanol over Ni-BEA catalysts: a BTL strategy. Int J Hydrogen Energy 41:1687816889. https://doi.org/10.1016/j.ijhydene.2016.07.149

97. Rossetti I, Lasso J, Compagnoni $\mathrm{M}$ et al (2015) $\mathrm{H}_{2}$ production from bioethanol and its use in fuel-cells. Chem Eng Trans 43:229-234. https://doi.org/10.3303/CET1543039

98. Ramis G, Rossetti I, Tripodi A, Compagnoni M (2017) Diluted bioethanol solutions for the production of hydrogen and ethylene. Chem Eng Trans. https://doi.org/10.3303/CET1757278

99. Vizcaino A, Carrero A, Calles J (2007) Hydrogen production by ethanol steam reforming over $\mathrm{Cu}-\mathrm{Ni}$ supported catalysts. Int J Hydrogen Energy 32:1450-1461. https://doi.org/10.1016/j. ijhydene.2006.10.024

100. Wu Y-J, Santos JC, Li P et al (2014) Simplified kinetic model for steam reforming of ethanol on a Ni/Al $\mathrm{Al}_{2} \mathrm{O}_{3}$ catalyst. Canad J Chem Eng 92:116-130. https://doi.org/10.1002/cjce.21773

101. Cunha AF, Wu YJ, Santos JC, Rodrigues AE (2012) Steam reforming of ethanol on copper catalysts derived from hydrotalcite-like materials. Ind Eng Chem Res 51:13132-13143. https://doi.org/10.1021/ie301645f

102. Zanchet D, Santos JBO, Damyanova S et al (2015) Toward understanding metal-catalyzed ethanol reforming. ACS Catal 5:3841-3863. https://doi.org/10.1021/cs5020755

103. Finocchio E, Rossetti I, Ramis G (2013) Redox properties of $\mathrm{Co}-$ and $\mathrm{Cu}$-based catalysts for the steam reforming of ethanol. Int J Hydrogen Energy 38:3213-3225. https://doi.org/10. 1016/j.ijhydene.2012.12.137

104. Nichele V, Signoretto M, Pinna F et al (2014) Ni/ZrO 2 catalysts in ethanol steam reforming: Inhibition of coke formation by 
CaO-doping. Appl Catal B 150-151:12-20. https://doi.org/10. 1016/j.apcatb.2013.11.037

105. Nichele V, Signoretto M, Menegazzo F et al (2014) Hydrogen production by ethanol steam reforming: effect of the synthesis parameters on the activity of $\mathrm{Ni} / \mathrm{TiO}_{2}$ catalysts. Int J Hydrogen Energy 39:4252-4258. https://doi.org/10.1016/j.ijhydene.2013. 12.178

106. Ramis G, Rossetti I, Finocchio E et al (2015) Metal dispersion and interaction with the supports in the coke production over ethanol steam reforming catalysts. Progress Clean Energy 1:695-711

107. Nichele V, Signoretto M, Pinna F et al (2015) Bimetallic Ni$\mathrm{Cu}$ catalysts for the low-temperature ethanol steam reforming: importance of metal-support interactions. Catal Lett 145:549558. https://doi.org/10.1007/s10562-014-1414-2

108. Furtado AC, Alonso CG, Cantão MP, Fernandes-Machado NRC (2009) Bimetallic catalysts performance during ethanol steam reforming: influence of support materials. Int J Hydrogen Energy 34:7189-7196. https://doi.org/10.1016/j.ijhydene. 2009.06.060

109. Xu J, Froment GF (1989) Methane steam reforming, methanation and water-gas shift: I. Intrinsic kinetics. AIChE J 35:88-96. https://doi.org/10.1002/aic.690350109

110. Mas V, Kipreos R, Amadeo N, Laborde M (2006) Thermodynamic analysis of ethanol/water system with the stoichiometric method. Int J Hydrogen Energy 31:21-28. https://doi.org/10. 1016/j.ijhydene.2005.04.004

111. Mas V, Bergamini ML, Baronetti G et al (2008) A kinetic study of ethanol steam reforming using a nickel based catalyst. Top Catal 51:39-48. https://doi.org/10.1007/s11244-008-9123-y

112. Rossetti I, Compagnoni M, Torli M (2015) Process simulation and optimisation of $\mathrm{H}_{2}$ production from ethanol steam reforming and its use in fuel cells. 1. Thermodynamic and kinetic analysis. Chem Eng J 281:1024-1035. https://doi.org/10.1016/j.cej.2015.08.025

113. Akpan E, Akande A, Aboudheir A et al (2007) Experimental, kinetic and 2-D reactor modeling for simulation of the production of hydrogen by the catalytic reforming of concentrated crude ethanol ( CRCCE ) over a Ni-based commercial catalyst in a packed-bed tubular reactor. Chem Eng Sci 62:3112-3126. https:// doi.org/10.1016/j.ces.2007.03.006

114. Akande A, Aboudheir A, Idem R, Dalai A (2006) Kinetic modeling of hydrogen production by the catalytic reforming of crude ethanol over a co-precipitated $\mathrm{Ni}-\mathrm{Al}_{2} \mathrm{O}_{3}$ catalyst in a packed bed tubular reactor. Int J Hydrogen Energy 31:1707-1715. https://doi. org/10.1016/j.ijhydene.2006.01.001

115. Patel M, Jindal TK, Pant KK (2013) Kinetic study of steam reforming of ethanol on Ni-based ceria-zirconia catalyst. Ind Eng Chem Res 52:15763-15771. https://doi.org/10.1021/ie401570s

116. Sahoo DR, Vajpai S, Patel S, Pant KK (2007) Kinetic modeling of steam reforming of ethanol for the production of hydrogen over $\mathrm{Co} / \mathrm{Al}_{2} \mathrm{O}_{3}$ catalyst. Chem Eng J 125:139-147. https://doi. org/10.1016/j.cej.2006.08.011

117. Patel MP, Shah N, Ashe R (2011) Robust optimisation methodology for the process synthesis of continuous technologies. In: Computer Aided Chemical Engineering. pp 351-355

118. Tripodi A, Compagnoni M, Martinazzo R et al (2017) Process simulation for the design and scale up of heterogeneous catalytic process: kinetic modelling issues. Catalysts. https://doi.org/10. 3390/catal7050159

119. Wu YJ, Li P, Yu JG et al (2013) Sorption-enhanced steam reforming of ethanol on NiMgAl multifunctional materials: experimental and numerical investigation. Chem Eng J 231:36-48. https:// doi.org/10.1016/j.cej.2013.06.125

120. Choi Y, Stenger HG (2003) Water gas shift reaction kinetics and reactor modeling for fuel cell grade hydrogen. J Power Sources 124:432-439. https://doi.org/10.1016/S0378-7753(03)00614-1
121. Sander R (2015) Compilation of Henry's law constants (version 4.0) for water as solvent. Atmos Chem Phys 15:4399-4981. https://doi.org/10.5194/acp-15-4399-2015

122. Young CL, Clever HL (1987) IUPAC Solubility Data Series Methane, volume 27/28

123. Wilhelm E, Battino R, Wilcock RJ (1977) Low-pressure solubility of gases in liquid water. Chem Rev 77:219-262. https://doi. org/10.1021/cr60306a003

124. Valtz A, Chapoy A, Coquelet C et al (2004) Vapour-liquid equilibria in the carbon dioxide-water system, measurement and modelling from 278.2 to 318.2 K. Fluid Phase Equilib 226:333-344. https://doi.org/10.1016/j.fluid.2004.10.013

125. Crovetto R, Fernández-Prini R, Japas ML (1982) Solubilities of inert gases and methane in $\mathrm{H}_{2} \mathrm{O}$ and in $\mathrm{D}_{2} \mathrm{O}$ in the temperature range of 300 to $600 \mathrm{~K}$. J Chem Phys 76:1077-1086. https://doi. org/10.1063/1.443074

126. Young CL (1981) IUPAC solubility data series: hydrogen and deuterium. Pergamon Press, Oxford

127. https://biorrefineria.blogspot.com/2015/08/cellulosic-ethanolbiorefineries.html

128. Miltner A, Wukovits W, Pröll T, Friedl A (2010) Renewable hydrogen production: a technical evaluation based on process simulation. J Clean Prod 18:S51-S62. https://doi.org/10.1016/J. JCLEPRO.2010.05.024

129. Carrara A, Perdichizzi A, Barigozzi G (2010) Simulation of an hydrogen production steam reforming industrial plant for energetic performance prediction. Int J Hydrogen Energy 35:34993508. https://doi.org/10.1016/J.IJHYDENE.2009.12.156

130. Lang P, Denes F, Hegely L (2017) Comparison of different amine solvents for the absorption of $\mathrm{CO}_{2}$. Chem Eng Trans 61:11051110. https://doi.org/10.3303/CET1761182

131. Yang S-I, Choi D-Y, Jang S-C et al (2008) Hydrogen separation by multi-bed pressure swing adsorption of synthesis gas. Adsorption 14:583-590. https://doi.org/10.1007/s10450-008-9133-x

132. Lopes FVS, Grande CA, Ribeiro AM et al (2009) Adsorption of $\mathrm{H}_{2}, \mathrm{CO}_{2}, \mathrm{CH}_{4}, \mathrm{CO}, \mathrm{N}_{2}$ and $\mathrm{H}_{2} \mathrm{O}$ in activated carbon and zeolite for hydrogen production. Sep Sci Technol 44:1045-1073. https:// doi.org/10.1080/01496390902729130

133. Tripodi A, Pizzonia A, Bahadori E, Rossetti I (2018) Integrated plant layout for heat and power cogeneration from diluted bioethanol. ACS Sustain Chem Eng 6:5358-5369. https://doi.org/10. 1021/acssuschemeng.8b00144

134. Aden a, Ruth M, Ibsen K, et al (2002) Lignocellulosic biomass to ethanol process design and economics utilizing co-current dilute acid prehydrolysis and enzymatic hydrolysis for corn stover. National Renewable Energy Laboratory-NREL Medium: ED; Size, $p$ 154. NREL/TP-510-32438

135. Dias MOS, Ensinas AV, Nebra SA et al (2009) Production of bioethanol and other bio-based materials from sugarcane bagasse: integration to conventional bioethanol production process. Chem Eng Res Des 87:1206-1216. https://doi.org/10. 1016/J.CHERD.2009.06.020

136. Pardo-Planas O, Atiyeh HK, Phillips JR et al (2017) Process simulation of ethanol production from biomass gasification and syngas fermentation. Biores Technol 245:925-932. https://doi. org/10.1016/j.biortech.2017.08.193

137. Xuan J, Leung MKH, Leung DYC, Ni M (2009) A review of biomass-derived fuel processors for fuel cell systems. Renew Sustain Energy Rev 13:1301-1313. https://doi.org/10.1016/J. RSER.2008.09.027

Publisher's Note Springer Nature remains neutral with regard to jurisdictional claims in published maps and institutional affiliations. 